\title{
Exhumation of the southern Pyrenean fold-thrust belt (Spain) from orogenic growth to decay
}

\author{
Caitlin R. Rushlow, ${ }^{1,2}$ Jason B. Barnes, ${ }^{1}$ Todd A. Ehlers, ${ }^{3}$ and Jaume Vergés ${ }^{4}$ \\ Received 30 June 2012; revised 25 December 2012; accepted 25 February 2013; published 16 August 2013.
}

[1] The deformation and exhumation history of an orogen reflects the interactions between tectonic and surface processes. We investigate orogenic wedge deformation, erosion, and sedimentation in the Pyrenees by (a) quantifying the spatiotemporal patterns of exhumation across the southern fold-thrust belt (FTB) with bedrock apatite fission track (AFT) thermochronology and (b) comparing the results with existing deformation, exhumation, and sedimentation chronologies. Eighteen new samples record exhumation during and after orogenesis between 90 and 10 Ma. Rocks from the range core (Axial Zone) record rapid exhumation that progresses east to west and north to south, consistent with patterns of tectonically driven uplift. Synorogenic sediments shed into piggyback basins on the southern fold-thrust belt during mountain building retain a detrital exhumation signal from the Axial Zone. In contrast, samples from other structural positions record exhumation of the thin-skinned Pyrenean thrust sheets, suggesting sediment burial and heating of sufficient magnitudes to reset the AFT system $(>\sim 3 \mathrm{~km})$. In some locations, exhumation of these fold-thrust structures is likely an erosional response to thrust-driven rock uplift. We identify an exhumation phase $\sim 25-20$ Ma that occurs along the central and eastern Spanish Pyrenees at the boundary between thick- and thin-skinned portions of the wedge. We suggest that this distributed exhumation event records (a) a taper response in the southern orogenic wedge to sediment loading and/or (b) a shift to wetter, stormier climate conditions following convergence-driven uplift and full topographic development. A final exhumation phase between $\sim 20$ and 10 Ma may record the excavation of the southern fold-thrust system following base level lowering in the Ebro Basin.

Citation: Rushlow, C. R., J. B. Barnes, T. A. Ehlers, and J. Vergés (2013), Exhumation of the southern Pyrenean fold-thrust belt (Spain) from orogenic growth to decay, Tectonics, 32, 843-860, doi:10.1002/tect.20030.

\section{Introduction}

[2] Tectonic and surfaces processes play evolving roles in the development of linked thrust belt-foreland basin systems as they shift from active shortening to postorogenic decay [Allen, 2008]. Collisional mountain ranges are traditionally modeled in cross section as bivergent critical wedges [e.g., Beaumont et al., 1992; Mugnier et al., 1997] that accommodate shortening by oscillating around an equilibrium (critical) state defined by the mean topographic gradient and the basal décollement (taper) [Chapple, 1978]. Deformation, erosion, and sedimentation redistribute mass

\footnotetext{
${ }^{1}$ Department of Geological Sciences, University of North Carolina, Chapel Hill, North Carolina, USA.

${ }^{2}$ Department of Geosciences, Idaho State University, Pocatello, Idaho, USA.

${ }^{3}$ Department of Geosciences, University of Tübingen, Tübingen, Germany.

${ }^{4}$ Group Dynamics of the Lithosphere, Institute of Earth Sciences, "Jaume Almera," ICTJA-CSIC, Barcelona, Spain.

Corresponding author: C. R. Rushlow, Department of Geological Sciences, University of North Carolina, Chapel Hill, NC, USA. (rushcait@isu.edu)

(C) 2013. American Geophysical Union. All Rights Reserved. 0278-7404/13/10.1002/tect.20030
}

within an evolving wedge, influencing the topographic and structural expression of convergent tectonics [Davis et al., 1983; Dahlen et al., 1984]. After orogenesis ceases, processes such as isostatic rebound [Gilchrist et al., 1994], drainage basin reorganization [Garcia-Castellanos et al., 2003], and global-to-regional climate change [Whipple, 2009] can continue to alter the form of the mountain range. Therefore, quantifying the history of deformation, erosion, and sedimentation is important for understanding orogen evolution.

[3] The geometry of collisional orogens tends toward asymmetry across strike, with a wider pro-wedge forming over the underthrusting plate and a narrower retro-wedge forming over the overriding plate [Willett et al., 1993; Sinclair et al., 2005]. Orographic focusing of precipitation can enhance or even reverse this asymmetry [Willett, 1999]. Thermochronology provides a useful tool for understanding orogen evolution by tracking the thermal histories and trajectories of material that moved through an orogen [Batt and Brandon, 2002; Reiners and Brandon, 2006]. Studies often employ bedrock thermochronometer sampling on a single transect across an orogen, leading to a twodimensional understanding of processes affecting orogen evolution [e.g., Brandon et al., 1998; Fitzgerald et al., 1999]. However, this approach oversimplifies the mountain range, neglecting the effects of factors such as oblique 
convergence [Whitchurch et al., 2011], crustal heterogeneities [Beaumont et al., 2000], and regional climate gradients in controlling three-dimensional mountain belt form and evolution.

[4] The Pyrenees are well suited to studying orogen evolution both across and along strike. Formed from Late Cretaceous to early Miocene ( $\sim 80-20 \mathrm{Ma})$ continental collision of Iberia and Eurasia [Sibuet et al., 2004], this presently inactive mountain range accommodated moderate but variable shortening magnitudes (<165-80 km) along strike [Muñoz, 1992; Vergés et al., 1995; Teixell, 1998; Beaumont et al., 2000]. Previous studies extensively investigated erosional exhumation in the range interior with a particular focus on the central Pyrenees. These studies suggest that variations in surface mass flux across the wedge and into the adjacent basins strongly impacted the development and architecture of the range [e.g., Morris et al., 1998; Fitzgerald et al., 1999; Sinclair et al., 2005; Whitchurch et al., 2011; Fillon and van der Beek, 2012]. Although the history of deformation and sedimentation within and adjacent to the southern fold-thrust belt (FTB) is well constrained [e.g., Burbank et al., 1992a; Hogan and Burbank, 1996; Vergés and Burbank, 1996; Rahl et al., 2011], the relationship with exhumation on the thin-skinned portion of the wedge remains poorly quantified. Zircon fission track samples from the southern Pyrenees have an inherited exhumation signal from the range interior [Filleaudeau et al., 2011; Whitchurch et al., 2011], but pilot apatite (U-Th)/He samples from the region are reset [Fillon et al., 2010], hinting that lower-temperature thermochronometers, such as fission tracks and (U-Th)/He in apatite, may be appropriate to target exhumation patterns on the thin-skinned FTB. Recent work highlights the importance of diachronous along-strike uplift on sediment production and routing early in the range history [Whitchurch et al., 2011], but the continued effects of topographic development remain unknown because the sedimentary record extends to only $\sim 28 \mathrm{Ma}$.

[5] In this study, we use bedrock apatite fission track (AFT) thermochronology along the southern Pyrenean margin to extend constraints on spatiotemporal patterns of exhumation along strike and improve our understanding of the relationships between tectonic and surface processes during orogen development. We interpret our data set within the context of a series of balanced regional cross sections, correlate exhumation timing with magnetostratigraphic constraints on deposition and deformation, and integrate our data with previous AFT data sets. The thermal sensitivity of AFT thermochronology allows us to distinguish between phases when the thin-skinned FTB acted as a sediment source and sink during and after orogenesis. Our results provide the first direct evidence of significant erosion of the southern FTB after known phases of structural development. Unreset to partially reset samples from the GrausTremp Basin support interpretations of moderate syntectonic sediment burial of the southern FTB during Ebro foreland basin closure. We identify synchronous along-strike exhumation at the boundary between the thin-skinned FTB and the range interior during the final phases of orogenesis. While previous work attributes exhumation during this time period in the central Pyrenees to adjustment in response to sediment loading [Sinclair et al., 2005; Fillon et al., 2012], the structural heterogeneity between the FTB in the central and eastern Pyrenees calls this mechanism into question, at least for the eastern Pyrenees. Alternatively, we suggest a potential link between full along-strike topographic development during this time period and enhanced exhumation by orographic forcing that currently results in higher precipitation and summer storminess in the eastern Pyrenees than other regions of Spain.

\section{Geologic Setting}

[6] In the Early Cretaceous $(\sim 125 \mathrm{Ma})$, the Iberian plate rotated counterclockwise and began converging northward with Europe (Figure 1) [Sibuet et al., 2004]. Partial subduction of the Iberian lithosphere under the European plate and inversion of preexisting extensional faults accommodated shortening along the plate boundary [Vergés et al., 2002]. Major Pyrenean mountain building lasted from the Late Cretaceous to early Miocene ( $\sim 80-20 \mathrm{Ma})$ [Sinclair et al., 2005], forming a wedge with a central Axial Zone and flanking thrust belt-foreland basin systems (Figure 2) [Muñoz, 1992, Roure et al., 1989]. Beginning at $\sim 36 \mathrm{Ma}$, the southern Ebro foreland basin lost connection with the Atlantic, causing sediment shed from the exhuming Pyrenees to fill the basin and bury the southern FTB [Coney et al., 1996; Costa et al., 2009]. Preserved and variably deformed sediments reach elevations of $\sim 1700 \mathrm{~m}$ in the central Pyrenees and $\sim 2100 \mathrm{~m}$ in the eastern Pyrenees at present [Coney et al., 1996] or modeled paleoelevations of up to $2.6 \mathrm{~km}$ [Fillon and van der Beek, 2012]. Fluvial
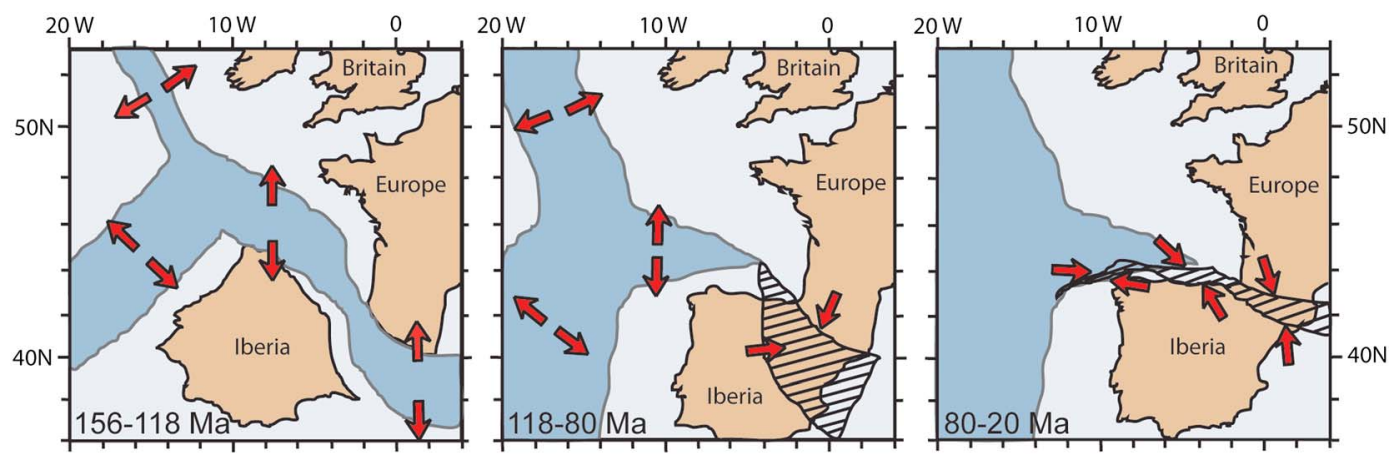

Figure 1. Kinematically restored plate motions based on paleomagnetic data with Europe fixed (simplified from Sibuet et al. [2004]). Arrows indicate relative plate motion directions. Hachured regions show where compression occurred, and dark blue represents ocean basin. 


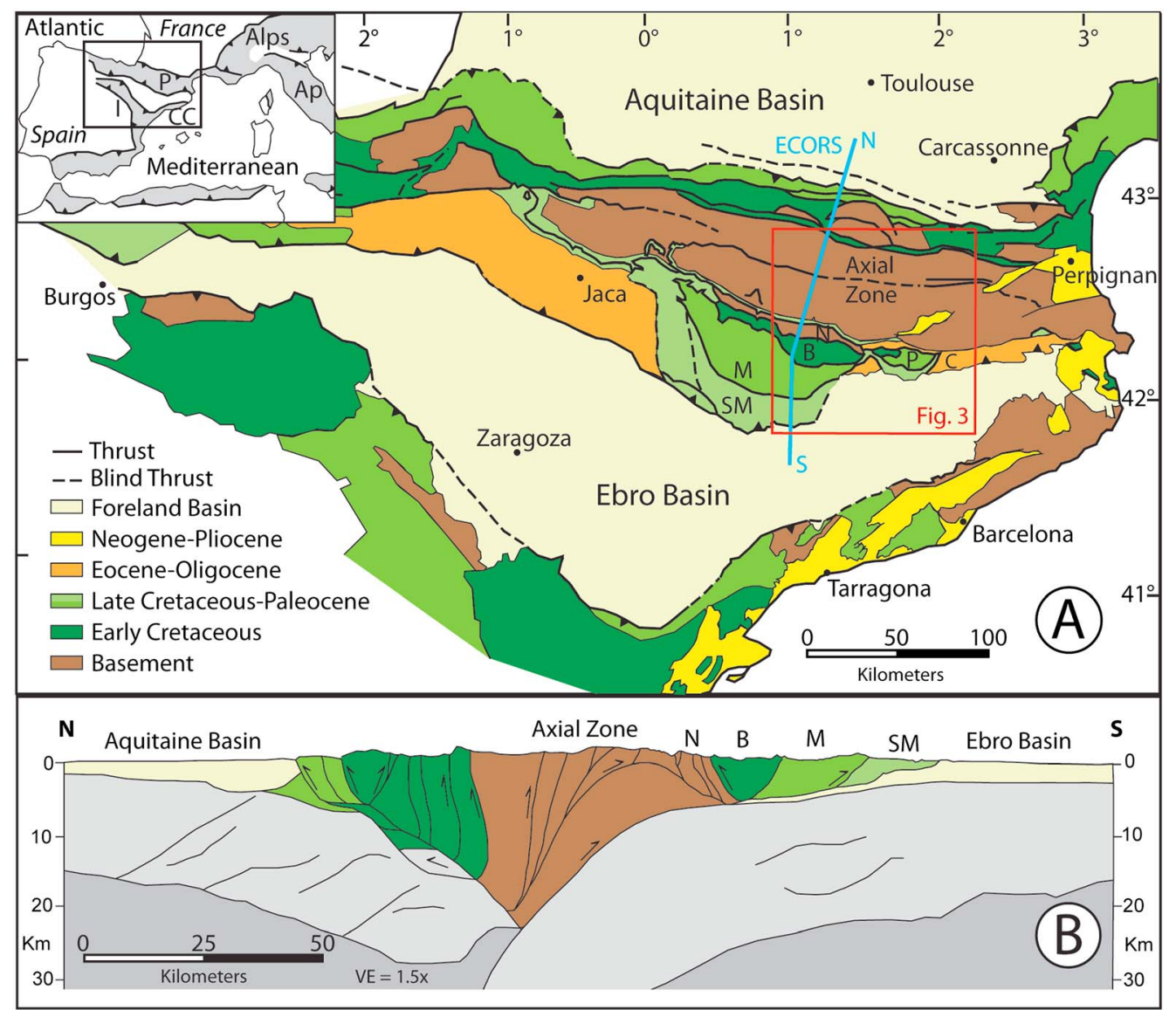

Figure 2. Geology of northeastern Iberia. (a) Simplified geologic map for the Pyrenees and surrounding regions (modified from Vergés and Burbank [1996]). Inset shows location and regional geographic context: Ap, Apennines; CC, Catalan Coastal Ranges; P, Pyrenees. Southern thrust sheets: B, Boixols thrust sheet; C, Cadi thrust sheet; M, Montsec thrust sheet; N, Nogueres Zone; P, Pedraforca; SM, Sierras Marginales. VE, vertical exaggeration. Red box is the study area, and the blue line indicates the ECORS seismic profile [Muñoz, 1992]. (b) Crustal-scale cross section along the ECORS transect (location in Figure 2a) (modified from Beaumont et al., 2000). Note the bivergent wedge geometry and central duplex versus marginal thin-skinned FTB structures of the Pyrenees.

excavation of the southern FTB followed Ebro Basin capture by the Mediterranean 13-8.5 Ma [Garcia-Castellanos et al., 2003; Arche et al., 2010]. Rifting related to the opening of the Valencia Trough caused uplift of the southeastern margin of the Ebro Basin and eastern Pyrenees during the Neogene and Quaternary (< 23 Ma) [Lewis et al., 2000].

[7] Pyrenean thrust belt structure, deformation timing, and spatial variations in shortening are well documented and relevant to the results of this study. Seismic reflection, balanced cross sections, and geodynamic models indicate maximum shortening of $\sim 165-147 \mathrm{~km}$ in the central Pyrenees along the Etude Continentale et Océanique par Reflexion et Refraction Sismique (ECORS) transect (Figure 2b) [Beaumont et al., 2000; Muñoz, 1992]. Shortening decreases away from ECORS, with minimum estimates of $\sim 125 \mathrm{~km}$ across the eastern Pyrenees [Vergés et al., 1995] and $\sim 80 \mathrm{~km}$ across the western Pyrenees [Teixell, 1998]. The ECORS deep reflection seismic survey shows that the Axial Zone basement rocks are deformed into a crustal-scale duplex structure [Muñoz, 1992]. The uppermost thrust sheet of the duplex forms the Nogueres Zone that acts as the backstop for the southern, thin-skinned portion of the FTB. To the east, the structural equivalent is the Freser antiformal stack (Figure 3) [Burbank et al., 1992b; Muñoz et al., 1986]. The thin-skinned portion of the FTB is widest in the central Pyrenees and consists of the Boixols, Montsec, and Sierras Marginales thrust sheets from north to south (Figures 2b and 3). Deformation across the central and eastern thinskinned FTB lasted from the Late Cretaceous to Oligocene ( 85-24 Ma). The south central thrust sheets form an imbricate fan system that generally propagated southward toward the foreland (Figures 2 and 3) [Vergés and Muñoz, 1990], but some north-vergent and out-of-sequence thrusting is evident from crosscutting stratigraphic relationships [e.g., Burbank et al., 1992a; Meigs et al., 1996; Meigs and Burbank, 1997; Ramos et al., 2002]. In the eastern Pyrenees, the Vallfogona Thrust marks the southern boundary of the Cadi and Pedraforca thrust sheets [Vergés et al., 2002]. Magnetostratigraphy and fault gouge dating constrain thrust sheet development in the eastern Pyrenees to a narrower time frame than the south central Pyrenees, from $\sim 54$ to $30 \mathrm{Ma}$ [Burbank et al., 1992b; Capote et al., 2002; Haines, 2008].

[8] Existing thermochronometer data quantify the broad exhumation patterns across the Pyrenees (Figure 3). 


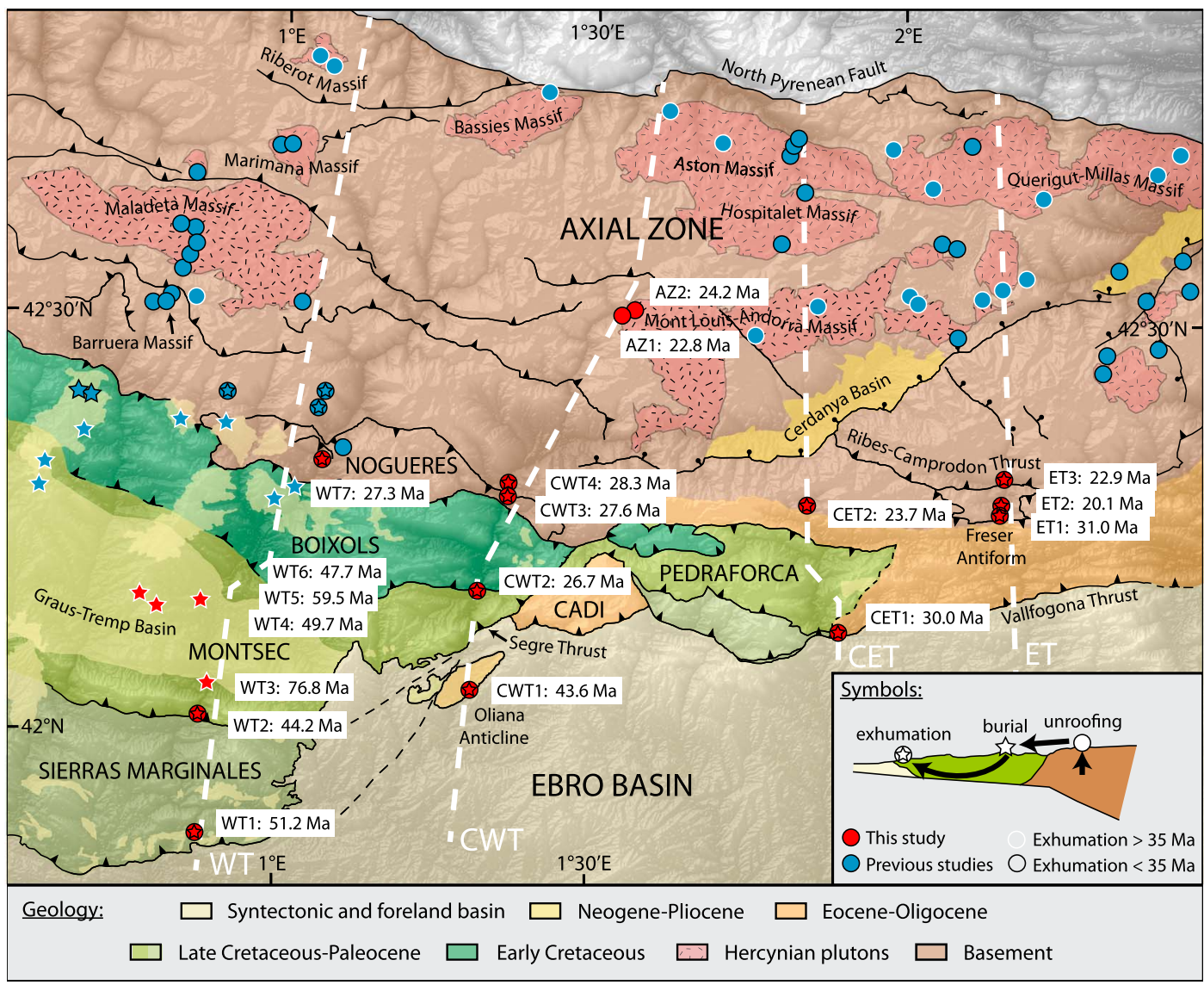

Figure 3. Topography, geology, and apatite fission track thermochronology data of the central and eastern Pyrenees. This synthesis highlights new and published bedrock apatite fission track (AFT) data within $10 \mathrm{~km}$ of the four transects. Inset shows our sample classification scheme, based on thermal model exhumation timing (white or black rim), location relative to where the sample most recently exhumed from AFT closure temperature (circle, star, or circled star; see discussion text for details), and data source (red or blue) [Morris et al., 1998; Fitzgerald et al., 1999; Gibson et al., 2007; Jolivet et al., 2007; Gunnell et al., 2009; Beamud et al., 2010]. Note that AFT pooled age, shown in white boxes alongside the sample number, and exhumation timing are not correspondent for discordant samples. WT, western transect; CWT, central western transect; CET, central eastern transect; ET, eastern transect. Geologic units were generalized from Mapa Geologic de Catalunya [2003], and topography is the $30 \mathrm{~m}$ Advanced Spaceborne Thermal Emission and Reflection Radiometer Global Digital Elevation Model (http://asterweb.jpl.nasa.gov/gdem-wist.asp).

Paired zircon U-Pb geochronology and detrital fission track thermochronology in the southern thrust belt and foreland basin found that convergence, shortening, and exhumation accelerated during the Late Cretaceous ( $\sim 80 \mathrm{Ma})$ [Filleaudeau et al., 2011] and that oblique convergence caused topography to develop diachronously along strike, from east to west between the Late Cretaceous and Miocene ( 80-20 Ma) (Figure 1) [Whitchurch et al., 2011]. Axial Zone Hercynian plutons exhumed most rapidly $\sim 35-30 \mathrm{Ma}$ in both the east [Morris et al., 1998] and the south [Fitzgerald et al., 1999], followed by slower exhumation starting at $30 \mathrm{Ma}$. The reduced exhumation from $30 \mathrm{Ma}$ is attributed to base level change in the Ebro foreland basin, where syntectonic sediment infill reduced local relief [Beamud et al., 2010]. ECORS transect thermochronometer data and discrete element modeling show an asymmetric exhumation pattern in the central Pyrenees [Fitzgerald et al., 1999; Sinclair et al., 2005]: exhumation migrated from north to south in response to the propagation of deformation and erosion across the pro-wedge. This asymmetric pattern caused orogenesis in the Pyrenees to end with syntectonic sediment blanketing of the southern range margin, pushing deformation from the FTB front back toward the pro-wedge hinterland, enhancing topography and accelerating erosion $\sim 20 \mathrm{Ma}$ in the Nogueres Zone (Figure 3) [Sinclair et al., 2005]. Remnants of this sediment blanket preserved in syntectonic basins on the southern thrust sheets record rapid cooling at $\sim 50-40$ and $\sim 30-25 \mathrm{Ma}$ associated with source region exhumation in the Axial Zone [Beamud et al., 2010; Rahl et al., 2011]. Samples from the lowest elevations in the piggyback basins record partial fission track annealing $<10 \mathrm{Ma}$, contemporaneous with fluvial excavation following Ebro Basin capture by the Mediterranean [Beamud et al., 2010]. Finally, thermokinematic modeling of the Axial Zone low-temperature thermochronometer data suggests that the Oligocene sediment cover filled in the paleotopography of the south central Pyrenees to depths of $\sim 2 \mathrm{~km}$ [Fillon and van der Beek, 2012]. 


\section{Apatite Fission Track Thermochronology}

\subsection{Overview}

[9] Apatite fission track (AFT) thermochronology uses the formation and temperature-dependent retention of damage trails called fission tracks that accumulate in apatite grains from the fission decay of ${ }^{238} \mathrm{U}$ to reconstruct the cooling histories of rocks in the uppermost crust [Fleischer et al., 1975; Gallagher et al., 1998]. Apatite grains retain fission tracks at temperatures below an effective closure temperature that depends on chemical composition $\left(\sim 110^{\circ} \mathrm{C}-\right.$ $120^{\circ} \mathrm{C}$ for fluorapatite), cooling rate, and the length of time spent at elevated temperatures [Ketcham et al., 1999]. An AFT age, measured from the ratio of parent to daughter $\left({ }^{238} \mathrm{U}\right.$ : fission tracks) products, represents the time since the grain cooled from below its closure temperature [Dodson, 1973]. Fission tracks form with lengths of $14.5-16 \mu \mathrm{m}$ [Gleadow et al., 1986] but shorten (anneal) over geologically significant timescales within a temperature window called the partial annealing zone (PAZ) that occurs over a range of $\sim 60^{\circ} \mathrm{C}$ [e.g., Gallagher et al., 1998].

[10] Many ( 20-40) apatite grains are analyzed in a bedrock sample, providing a distribution of fission track lengths and ages. The track length distribution preserves a record of the thermal history of the sampled rock as it cooled through the PAZ [Gleadow et al., 1986]. Summing the individual grain ages within each sample yields a pooled age [Donelick et al., 2005]. A chi-square test $\left(\chi^{2}\right)$ assesses the sample grain age variability [Galbraith, 1981]. A $P\left(\chi^{2}\right)>5 \%$ indicates minor grain age variability, and these samples are called concordant. A concordant sample pooled age represents the last time it cooled from closure temperature [Brandon et al., 1998; Galbraith, 1981; Green, 1981]. A $P\left(\chi^{2}\right)<5 \%$ indicates significant grain age variability, or discordance, and the pooled age is considered less meaningful [e.g., Green, 1981]. Discordance may result from multiple component ages or heterogeneous mineral properties, especially in sedimentary rocks that can have multiple sediment sources [Tagami and O'Sullivan, 2005]. Fission track diameter $\left(D_{\mathrm{par}}\right)$ is a kinetic parameter that relates to chemical composition among other factors and is commonly used to determine permissible time-temperature histories when inverse thermal modeling AFT data [Donelick et al., 2005; Ketcham et al., 1999]. Applying a combination of component age analysis and thermal modeling is a useful approach for constraining the full range of sample cooling histories permitted by measured ages and track lengths [Barnes et al., 2006, 2008].

\subsection{Sample Collection and Analysis}

[11] We collected bedrock samples from four across-strike transects of the central eastern Spanish Pyrenees to determine the regional exhumation patterns across the southern FTB margin (Figure 3). These transects follow the balanced cross sections of Vergés [1999]. We targeted the major FTB structures, including the Cadi, Montsec, and Sierras Marginales thrust sheets, the Nogueres Zone, the Oliana anticline, and the Freser antiformal stack. We sampled Permian, Triassic, and Cretaceous sandstones and Eocene turbidites, sandstones, and conglomerates. We also sampled a Paleozoic schist north of the Freser antiformal stack and the Mount Louis-Andorra pluton exposed in the Axial Zone. We used standard techniques to isolate apatite grains and measure fission track ages, lengths, and $D_{\text {par }}$ values (Appendix A). The fission track ages were determined using the laser ablation inductively coupled plasma-mass spectrometry method (LA-ICP-MS) [Donelick et al., 2005; Hasebe et al., 2004].

\subsection{Grain Age Analysis and Thermal Modeling}

[12] We applied both grain age analysis and thermal modeling to aid in the interpretation of the AFT data (see details in Appendices B and C). For all discordant samples $\left(P\left(\chi^{2}\right)<5 \%\right)$, we used binomial peak fitting [Galbraith and Green, 1990] to identify the statistically significant age components with the software RadialPlotter [Vermeesch, 2008]. We classified sample grain age distributions to assess the cooling history as reset (R), mixed reset (MR), partially reset (PR), or detrital (D) (cf. Brandon et al. [1998]). R and MR samples have one or more component ages that are younger than the bedrock deposition or crystallization age. A PR sample contains component ages both younger and older than the deposition or crystallization age. D samples have one or more component ages that are older than the deposition or crystallization age. In sedimentary samples, a D sample implies cooling during sediment sourcing prior to deposition, $\mathrm{R}$ and MR samples suggest cooling occurred after deposition and lithification, and a PR sample implies retained cooling signals from both prior to and after deposition and lithification.

[13] We used the thermal modeling software HeFTy [Ehlers, 2005; Ketcham, 2005] to constrain sample cooling histories consistent with the measured FT age, length, and $D_{\text {par }}$ data. We simulated geologic processes that the apatite grains experienced such as unroofing, erosion and burial, and postdepositional exhumation (Figure 3, inset) by progressively incorporating time-temperature constraints on inverse models for each sample (see details in Appendix B). We report time-temperature path envelopes that encompass the common merit values of 0.5 (good model fits) and 0.05 (acceptable model fits) from a Kuiper statistical test [Ketcham, 2005]. Because our sampling locations were unaffected by Cenozoic volcanism or extension [e.g., Vergés et al., 2002], we attribute recent thermochronometer-recorded cooling to erosional exhumation.

\section{Results}

\subsection{Overview}

[14] We report AFT data for 18 bedrock samples from Cambrian through Eocene sandstones, conglomerates, schists, and granodiorites exposed across the southern Axial Zone and FTB of the Spanish Pyrenees (Figure 3). Sample grain age and track length yields range from maximum (40 ages, 200+ track lengths) to very poor (3 ages, 5 track lengths). Sample pooled ages range from Late Cretaceous to early Miocene (76.8-20.1 Ma) with mean track lengths from 15.1 to $12.9 \mu \mathrm{m}$, implying fast to moderate cooling through the PAZ (Table 1). The pooled ages, identical within error to the central ages (Appendix C), suggest that the sampled bedrock cooled during Pyrenean orogenesis. However, since most samples are discordant, we used thermal modeling and grain age analysis to evaluate this simple interpretation. There is no correlation between $D_{\text {par }}$ and either track lengths or grain ages within our samples, indicating that sample discordance does not result from 
RUSHLOW ET AL.: EXHUMATION OF THE SOUTHERN PYRENEES

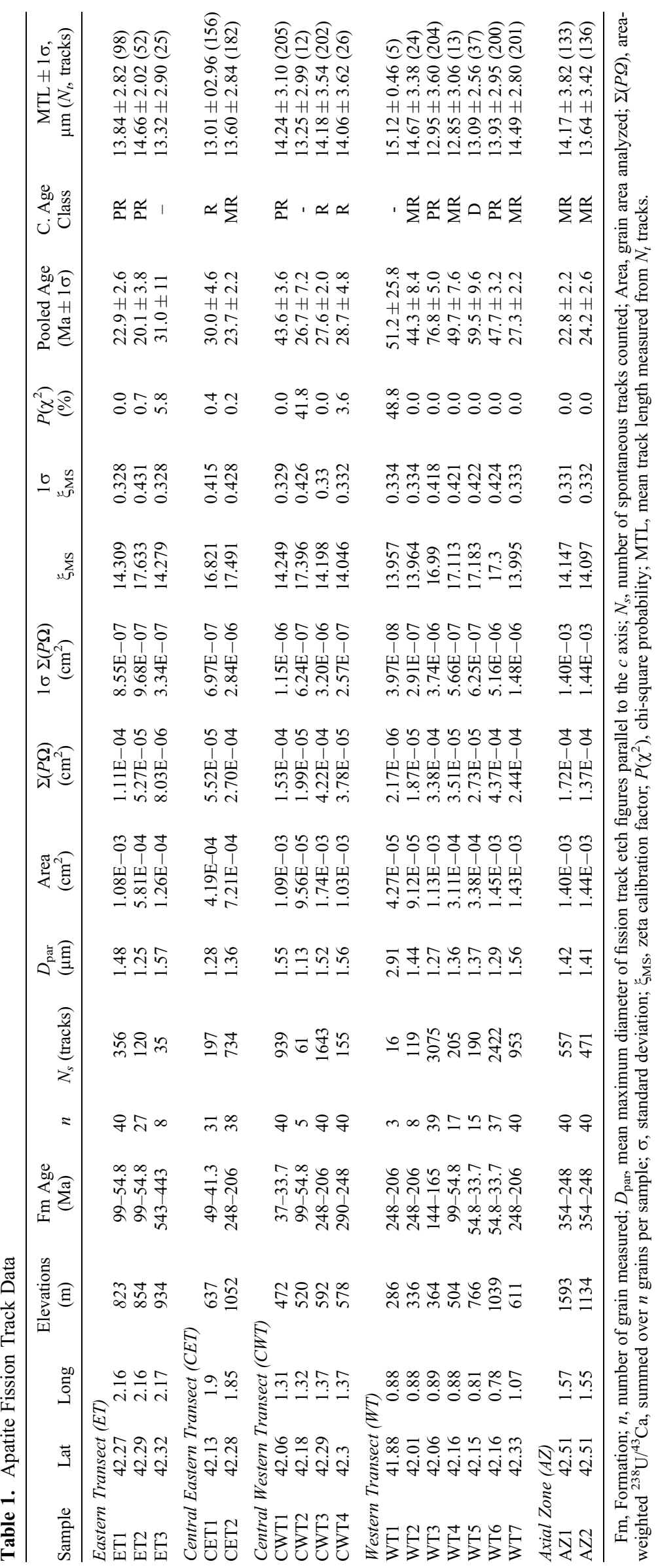




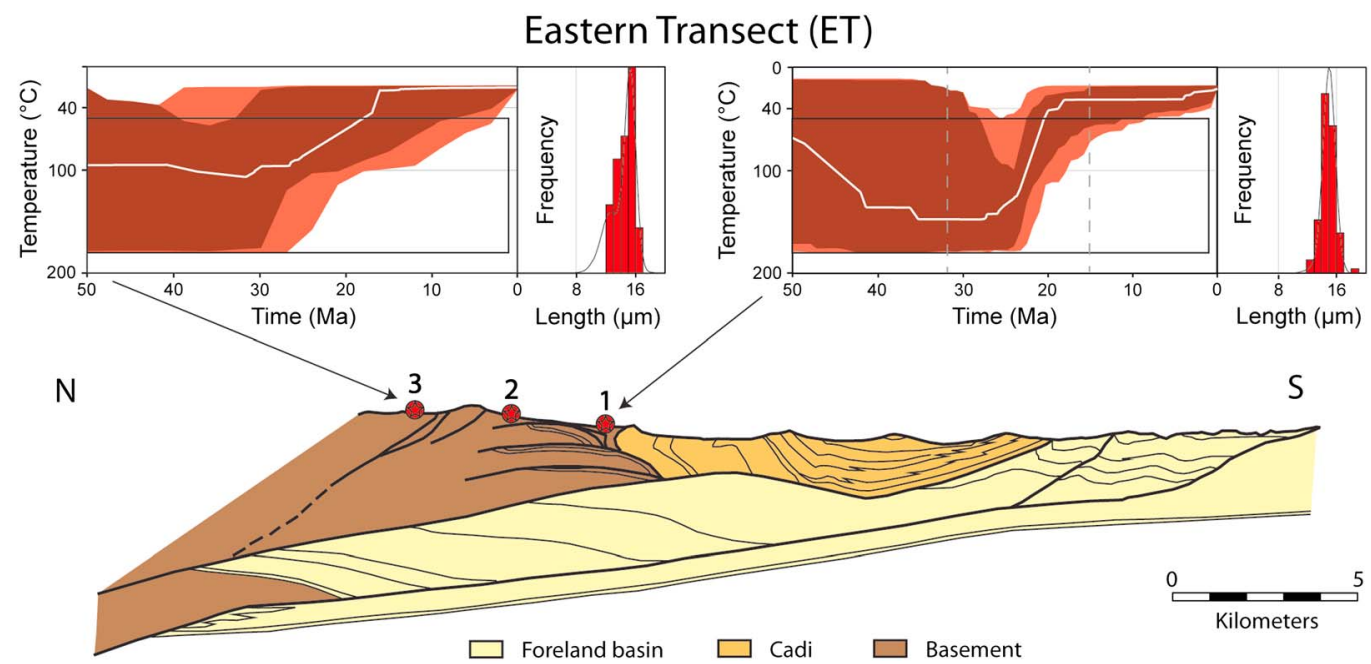

Figure 4. Structure of the eastern study transect (ET, location in Figure 3) (simplified from Vergés [1999]), numbered bedrock apatite fission track sample locations (symbol description in Figure 3, inset), and selected permissible time-temperature histories modeled with HeFTy [Ketcham, 2005]. Thermal envelopes show the range of good (dark red) and acceptable (light red) model fits. The white line is the best fit model path. Black boxes are modeling constraints (see methods for details). Horizontal gray lines highlight the partial annealing zone. Dashed vertical lines represent sample component ages determined using RadialPlotter [Vermeesch, 2008] (Appendix C). The track length distribution (red bars) and best fit model (line) are shown in the right panels.

variable kinetic properties but instead most likely reflects multiple age populations, although $\mathrm{U}$ loss could also play a role [Brandon et al., 1998; Ketcham et al., 1999]. All samples except one (WT1) have low mean $D_{\text {par }}$ values $(<1.6 \mu \mathrm{m})$, suggesting that they contain thermally sensitive calcian-fluorapatite [Carlson et al., 1999; Donelick et al., 2005] with fission tracks that survive heating to $\sim 100^{\circ} \mathrm{C}$ and partially anneal between $\sim 100^{\circ} \mathrm{C}$ and $40^{\circ} \mathrm{C}$ (Figures 4-7) [Reiners and Brandon, 2006].

[15] Below, we summarize our results along the four FTB transects from east to west in the direction of increased shortening [Vergés et al., 2002], followed by the Andorra-Mount Louis pluton in the Axial Zone.
Samples are numbered from south to north, and representative thermal model results are shown in Figures 4-7. We focus on the onset timing of most recent rapid cooling predicted by the statistically "good" thermal model fits [Ketcham, 2005].

\subsection{Eastern Transect}

[16] We report results from three samples along the eastern transect (ET) (Figure 4). Two samples (ET1 and ET2) are from Late Cretaceous-Paleocene sandstone units of the Garumnian Formation exposed in the Freser antiformal stack. They have pooled ages of 23-20 Ma and moderate mean track lengths $(13.8-14.7 \mu \mathrm{m})$. Both samples are discordant

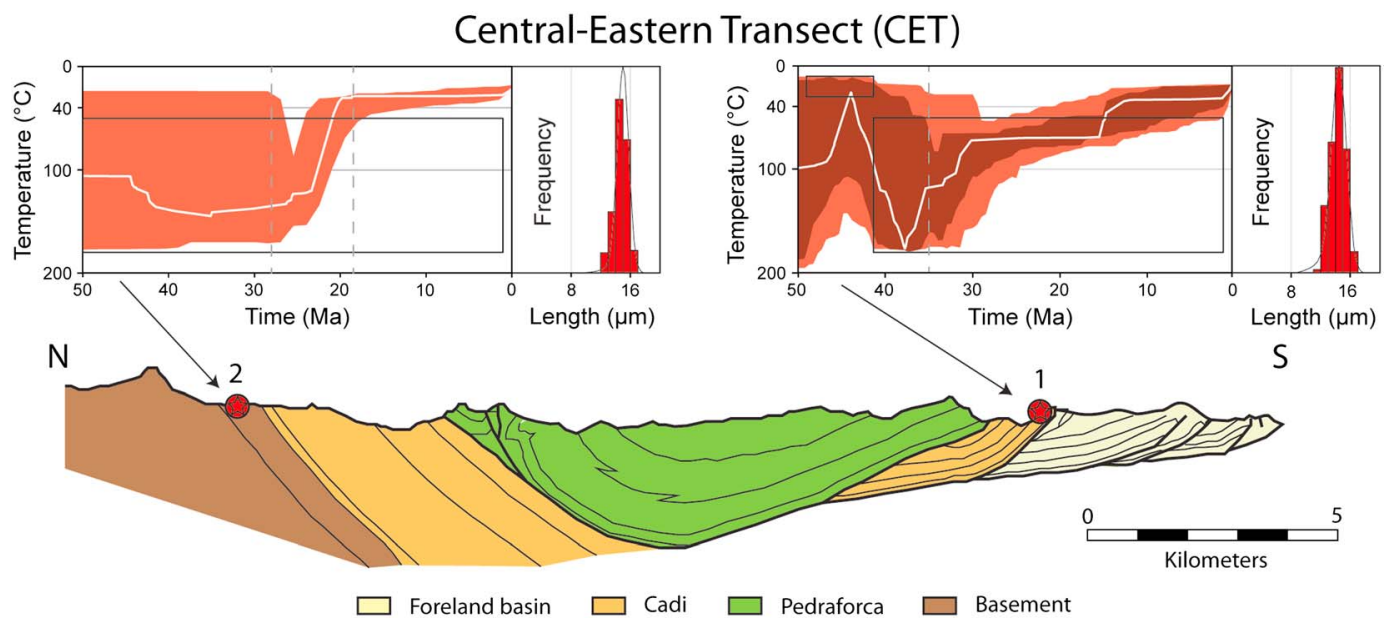

Figure 5. Structure of the central eastern transect (CET, location in Figure 3), bedrock apatite fission track sample locations, and associated thermal modeling results. See Figure 4 caption for details. 


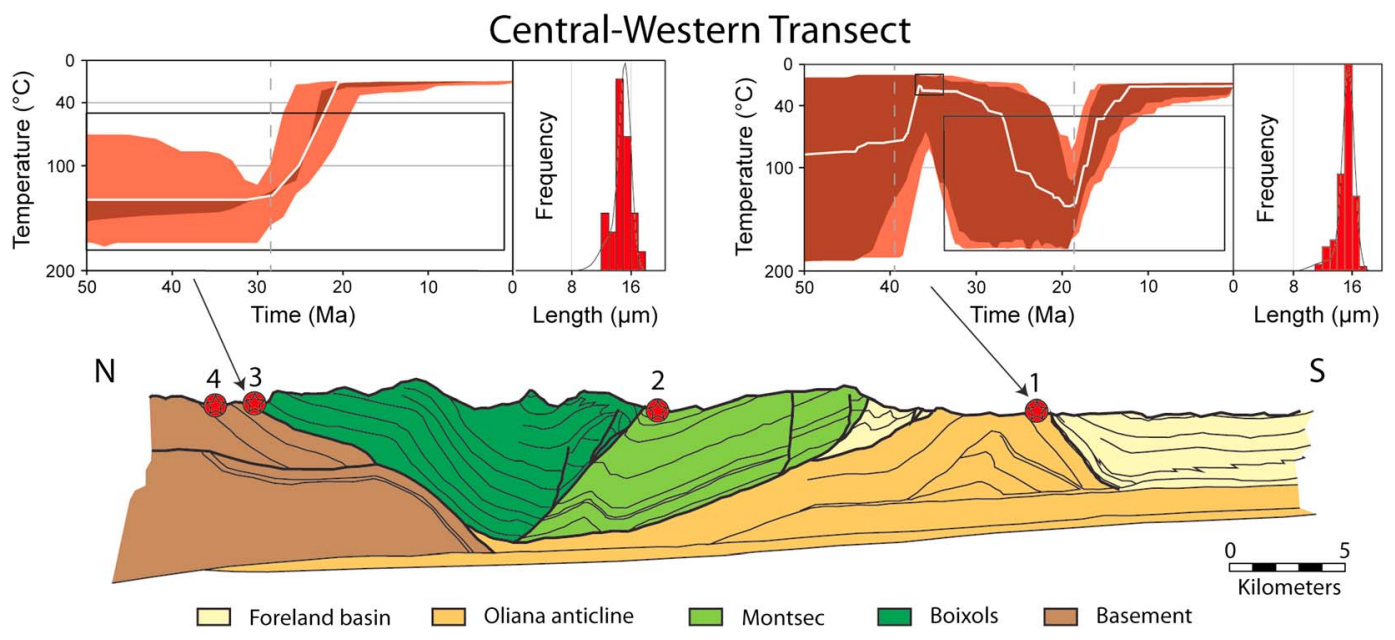

Figure 6. Structure of the central western transect (CWT, location in Figure 3), bedrock apatite fission track sample locations, and associated thermal modeling results. See Figure 4 caption for details.

and partially reset. Despite their apparent similarities, thermal modeling indicates that sample ET1 cooled rapidly through $100^{\circ} \mathrm{C}$ between 25 and $20 \mathrm{Ma}$, whereas sample ET2 produced no model fits. Sample ET3 is from quartzrich schist exposed on the hanging wall of the RibesCamprodon fault, north of the Freser antiformal stack. This sample has poor data quality (8 grains, 35 track lengths), and modeling suggests that rapid cooling began from $\sim 90^{\circ} \mathrm{C} 38-18 \mathrm{Ma}$.

\subsection{Central Eastern Transect}

[17] We report two samples from the Cadi thrust sheet to the south and north of the Pedraforca thrust sheet on the central eastern transect (CET) (Figure 5). Sample CET1 is from the middle Eocene Campdevanol Formation on the Vallfogona thrust hanging wall. It has a pooled age of $30 \pm 4.6 \mathrm{Ma}$ and a mean track length of $13.0 \pm 3.0 \mu \mathrm{m}$. CET1 is reset and slowly cooling through PAZ temperatures after 38-24 Ma. The northern sample, CET2, is from the lower Triassic Buntsandstein Formation [Gradstein et al., 2005] and has a pooled age of $23.7 \pm 2.2 \mathrm{Ma}$ and a mean track length of $13.6 \mu \mathrm{m}$. This sample has mixed reset ages, and acceptable thermal model fits indicate recent cooling through $\sim 110^{\circ} \mathrm{C} 27-21 \mathrm{Ma}$.

\subsection{Central Western Transect}

[18] We present four samples along the central western transect (CWT) (Figure 6). Sample CWT1 is from a conglomerate exposed on the southern limb of the Oliana anticline. The depositional age (33.7-37 Ma) of this sample is well constrained by high-resolution magnetostratigraphy [Burbank et al., 1992a], and it has a pooled age of $43.6 \pm 3.6$ $\mathrm{Ma}$ and a mean track length of $14.2 \pm 3.1 \mu \mathrm{m}$. Component age analysis shows that this sample is partially reset, and thermal modeling constrains rapid cooling from PAZ temperatures to a narrow window of $\sim 18-16 \mathrm{Ma}$. Sample CWT2 is from the Cretaceous sandstone of the Garumnian Formation and has a pooled age of $26.7 \pm 7.2 \mathrm{Ma}$ and a

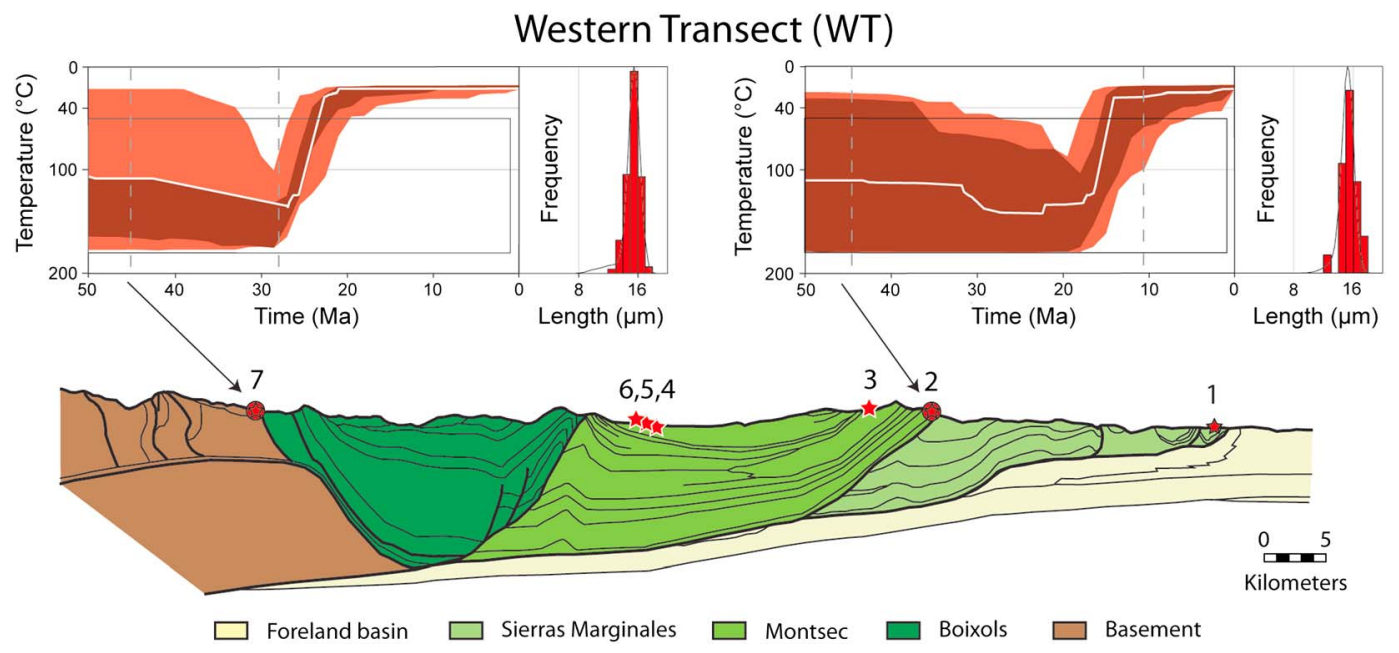

Figure 7. Structure of the western transect (WT, location in Figure 3), bedrock apatite fission track sample locations, and associated thermal modeling results. Structurally equivalent to the ECORS profile. See Figure 4 caption for details. 
mean track length of $13.3 \pm 2.9 \mu \mathrm{m}$. Modeling suggests this sample cooled from $\sim 90^{\circ} \mathrm{C}$ between 34 and $15 \mathrm{Ma}$. Samples CWT3 and CWT4 are from Triassic and Permian sandstones in the footwall of the Boixols back thrust and have similar pooled ages (27.6-28.7 Ma) and mean track lengths $(14.1-14.2 \mu \mathrm{m})$. Both samples are fully reset. Sample CWT3 cooled below $90^{\circ} \mathrm{C}$ between 25 and $24 \mathrm{Ma}$. CWT4 is less constrained but cooled between 36 and $18 \mathrm{Ma}$.

\subsection{Western Transect}

[19] We report seven samples on the western transect (WT), which is equivalent to the ECORS profile (Figures 2 and 7). The southernmost sample (WT1) is from the Triassic Keuper Formation exposed in the hanging wall of the Sierras Marginales thrust sheet. This sample is concordant, but because it has poor FT data quality (3 ages, 16 track lengths), permissible model paths define a broad time period (64-32 Ma) for rapid cooling from closure temperatures. Sample WT2 is from the Triassic Keuper Formation exposed on the Montsec thrust sheet. This mixed reset sample has a pooled age of $44.2 \pm 8.4 \mathrm{Ma}$, a mean track length of $14.7 \pm 3.4 \mu \mathrm{m}$, and rapidly cooled $18-13 \mathrm{Ma}$ from $\sim 100^{\circ} \mathrm{C}$. Sample WT3 is from the Cretaceous Marbore sandstone on the Montsec thrust sheet. It is partially reset and cooled slowly through the PAZ 90-45 Ma. Samples WT4-WT6 form an 500 m elevation transect within the Graus-Tremp Basin on the Montsec thrust sheet. These samples have Paleocene-to-Eocene pooled ages (47.7-59.5 Ma) and mean track lengths that increase up section, suggesting that the lower elevation samples from the profile spent more time in PAZ temperatures. WT4, a mixed reset sample from the Late Cretaceous-Paleocene Garumnian Formation at the profile base, began cooling 61-37 Ma. WT5, a detrital sample from Eocene sandstone in the middle of the profile, began cooling 71-53 Ma. Partially reset sample WT6, from the highest elevation, rapidly cooled from above PAZ temperatures between 52 and $41 \mathrm{Ma}$. Thermal models of WT5 and WT4 indicate slow recent cooling through PAZ temperatures. Finally, the northernmost sample (WT7) is from a Triassic sandstone in the Nogueres Zone and is mixed reset. WT7 cooled rapidly through closure temperature 29-23 Ma.

\subsection{Andorra-Mount Louis Pluton}

[20] Two Axial Zone granodiorite samples from the Andorra-Mount Louis pluton have similar pooled ages $(24.2-22.8 \mathrm{Ma})$, mean track lengths $(14.2-13.6 \mu \mathrm{m})$, and $D_{\text {par }}$ values $(1.4 \mu \mathrm{m})$. Both samples began to cool rapidly $25-20 \mathrm{Ma}$.

\section{Discussion}

\subsection{Unroofing, Burial, and Exhumation}

[21] The AFT analyses and thermal modeling results reveal that the rocks exposed in the southern Pyrenees have experienced a variety of cooling histories and trajectories through the upper crust. For sedimentary bedrock, AFTrecorded cooling could represent exhumation of the sedimentary rock parcel itself or an inherited (detrital) exhumation signal from the sediment source region. We use the term unroofing when discussing inherited exhumation and the term exhumation when discussing postdepositional exhumation (Figure 3, inset) and differentiate between the two possibilities by comparing the timing of exhumation with wedge-top deposition (Figure 8). When exhumation precedes or is contemporaneous with deposition, the apatite grains retain an inherited signal of erosion from the Axial Zone source region because burial and associated heating were not sufficient to reset the AFT system (Figures 3-8, red stars). This is the case for four of our samples from the Montsec thrust sheet and all of the Graus-Tremp Basin samples (Figure 8). Granitic cobbles from related syntectonic basins preserved on the Montsec and Boixols thrust sheets and Nogueres Zone have a similar inherited unroofing signal (Figures 3 and 8, blue stars) [Beamud et al., 2010; Rahl et al., 2011]. When sediment burial and heating is sufficient to partially or completely reset the AFT system, exhumation is recorded after deposition. The remaining sedimentary bedrock sampled from Cadi thrust sheet, Oliana anticline, Sierras Marginales thrust sheet, and Montsec thrust sheet experienced this type of postdepositional exhumation (Figures 3-8, red encircled stars).

\subsection{Variation in Exhumation Magnitudes}

[22] The spatial variability in the magnitude of exhumation across the southern Pyrenees is evident from the exposure of both sedimentary bedrock that retains an inherited exhumation signal and that experienced sufficient reexhumation to erase this inherited signal. The present geothermal gradient in the foreland basin is $30^{\circ} \mathrm{C} / \mathrm{km}$ to $35^{\circ} \mathrm{C} / \mathrm{km}$, and rapid deposition or sediment blanketing effects could have caused the paleogeothermal gradient to be either lower or higher, respectively [Fillon and van der Beek, 2012]. Therefore, we used $30^{\circ} \mathrm{C} / \mathrm{km}$ as a paleogeothermal gradient estimate [after Beamud et al., 2010], a closure temperature of $100^{\circ} \mathrm{C}$ because of the low mean $D_{\text {par }}$ in our samples, and a $20^{\circ} \mathrm{C}$ surface temperature to suggest an average depth to closure of $\sim 2.7 \mathrm{~km}$. Estimating that the lower limit of the PAZ extends to $40^{\circ} \mathrm{C}$, our data suggest that exhumation magnitudes were greater than $\sim 0.6 \mathrm{~km}$ in order to expose partially reset samples, but did not exceed $\sim 2.7 \mathrm{~km}$ in the interior of the Montsec thrust sheet (samples WT3-WT6). Our estimation agrees with previous structural estimates suggesting that $0.5-1 \mathrm{~km}$ of material was removed from the central Pyrenees wedge top after major episodes of deformation (post-28 Ma) based on the current wedge geometry, taper, and exposure of syntectonic conglomerates [Meigs and Burbank, 1997].

\subsection{Spatiotemporal Patterns of Synorogenic Exhumation}

[23] The Late Eocene was a time of abrupt change in the southern Pyrenees. Thrusting and duplex formation rapidly exhumed the south central Axial Zone 35 Ma [Muñoz, 1992; Morris et al., 1998; Fitzgerald et al., 1999; Beaumont et al., 2000; Sinclair et al., 2005]. Ebro foreland basin closure [Burbank et al., 1992a; Vergés and Burbank, 1996] caused drainage system reorientation from dominantly orogen parallel to orogen transverse (Figure 9) [Whitchurch et al., 2011]. On the thin-skinned FTB, only 
RUSHLOW ET AL.: EXHUMATION OF THE SOUTHERN PYRENEES

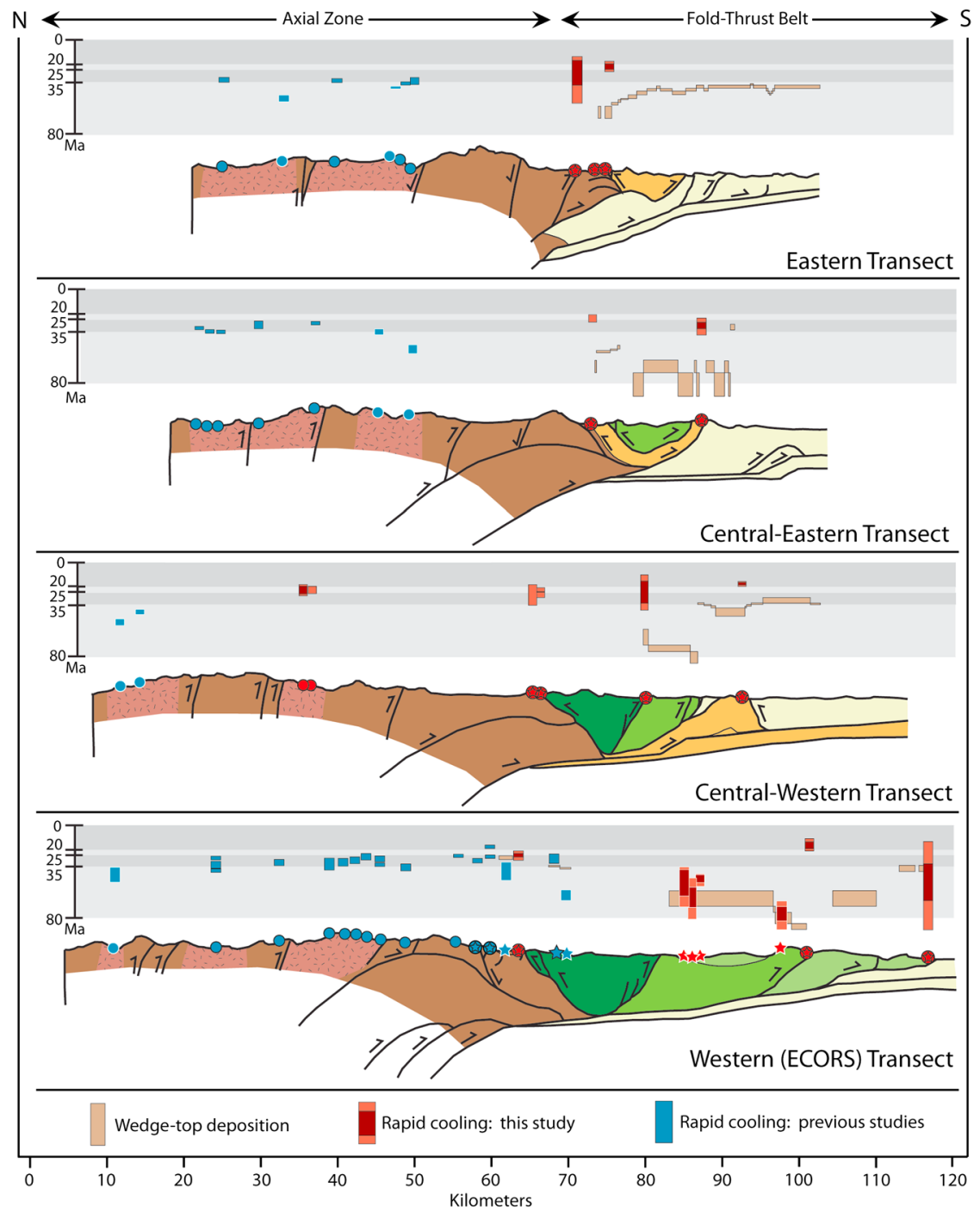

Figure 8. Simplified cross sections (from Vergés [1999]) along the four studied transects shown in Figures 3-7 synthesizing existing exhumation and sedimentation timing data across the central eastern Spanish Pyrenees [Beamud et al., 2010; Fitzgerald et al., 1999; Gibson et al., 2007; Gunnell et al., 2009; Jolivet et al., 2007; Morris et al., 1998; Rahl et al., 2011; Sinclair et al., 2005]. Overlap between timing of rapid cooling and deposition means the samples retain an inherited exhumation signal from the Axial Zone source region. Onset of rapid cooling from samples in this study is shown from the acceptable (red) and good (dark red) fit thermal model envelopes (e.g., Figures 4-7). Cross sections extend southward from the North Pyrenean Fault to the Ebro Basin. See Figure 3, inset, for sample symbol descriptions. Gray bars highlight the time windows shown in Figure 9.

the syntectonic basin sediments are known to preserve records of pre-35 Ma unroofing (Figures 3-8, white rimmed symbols). AFT data with a pre-35 Ma unroofing signal are clustered toward the north and east in the Axial Zone (Figures 3 and 9a).

[24] The overall distribution of exhumation before $35 \mathrm{Ma}$ reflects patterns of along- and across-strike structural development during Pyrenean orogenesis (Figure 9a). Exhumation started in the eastern Pyrenees in response to oblique convergence driving rock uplift and topographic growth (Figure 1). Exhumation subsequently decreased in the eastern Pyrenees, preserving a record of older exhumation as uplift shifted along strike to the central Pyrenees during the early to middle Eocene
25-40 Ma [Whitchurch et al., 2011]. While exhumation in the central Pyrenees began before $35 \mathrm{Ma}$, asymmetric convergence between the pro-wedge and the retro-wedge drove exhumation southward over time [Sinclair et al., 2005], removing most of the pre-35 Ma unroofing signal from the southern Axial Zone. Subsidence within the Graus-Tremp Basin and equivalent syntectonic basins generated enough accommodation space to preserve the earlier erosion signal in detrital apatites from the Axial Zone source region [see also Beamud et al., 2010; Rahl et al., 2011; this study]. In this way, the hinterland and thin-skinned FTB components of the orogenic wedge functioned together to redistribute mass on the surface in response to plate convergence. 
RUSHLOW ET AL.: EXHUMATION OF THE SOUTHERN PYRENEES
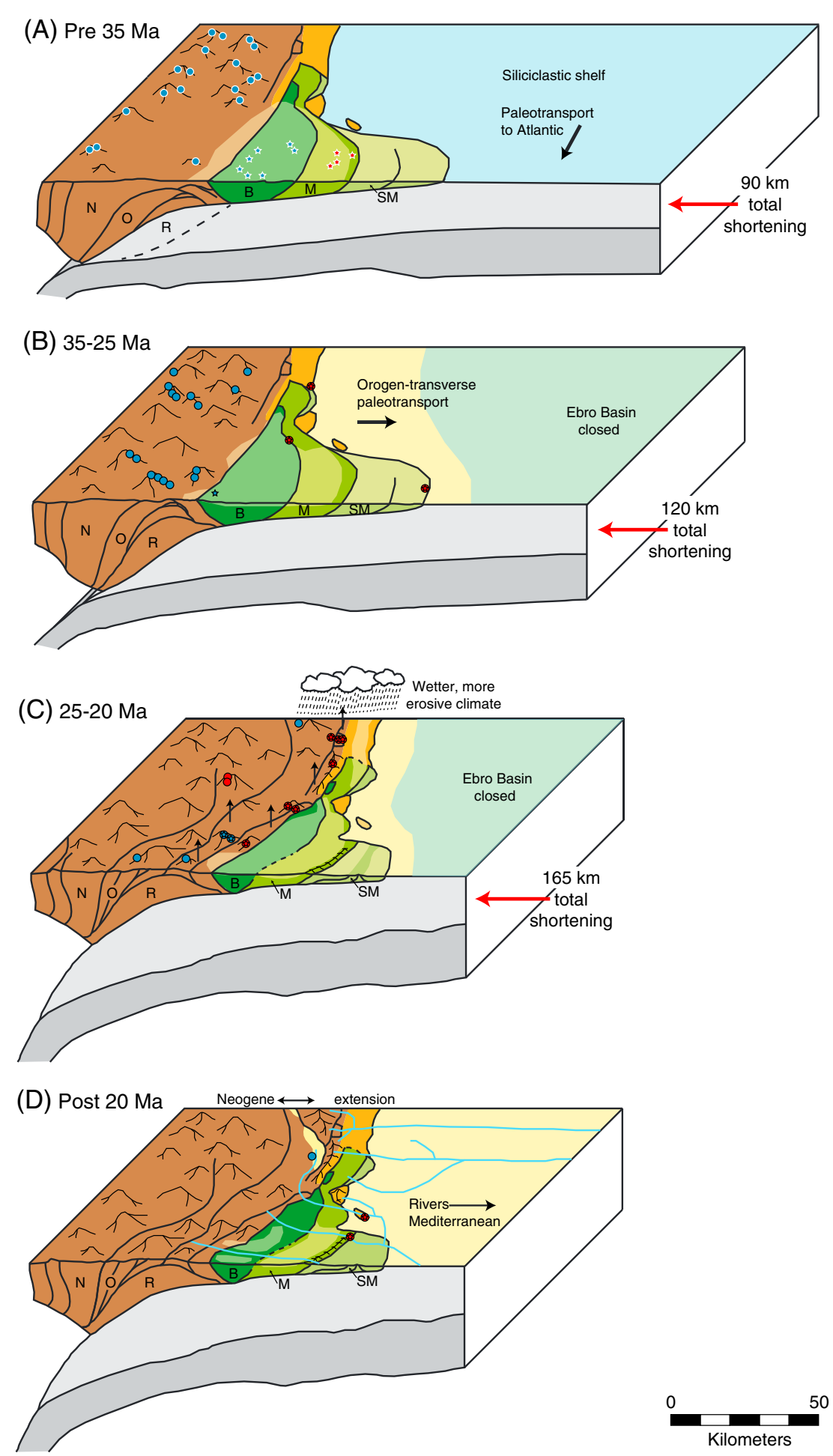

Figure 9. Summary of the synorogenic to postorogenic evolution of the central eastern Spanish Pyrenees. The Axial Zone develops diachronously from east to west [Whitchurch et al., 2011] and north to south in the central Pyrenees [Fitzgerald et al., 1999]. Closure of the Ebro Basin $~ 35$ Ma causes syntectonic sediments to bury the southern thrust sheets, forcing the wedge to deform internally to rebuild taper and accommodate shortening. Fluvial excavation follows when the basin connects with the Mediterranean $\sim 13-8.5$ Ma [Garcia-Castellanos et al., 2003]. N-S cross sectional view of the structural evolution of the southern orogenic wedge and total shortening estimates for the ECORS transect from Beaumont et al. [2000]. For the key to AFT sample location symbols, see Figure 3. Axial Zone antiformal stack thrust sheets: N, Nogueres; O, Orri; R, Rialp. Southern thrust sheets: B, Boixols; M, Montsec; SM, Sierras Marginales. 
[25] Significant exhumation occurs during periods of active deformation on the FTB from 35 to $25 \mathrm{Ma}$ (Figure 9b). For example, rapid cooling beginning between 34 and $29 \mathrm{Ma}$ on the Vallfogona thrust hanging wall (Figure 3) is likely an erosional exhumation response to thrust-driven rock uplift because it is coincident with final fault motion 36-30 Ma [Vergés and Burbank, 1996]. Emplacement of the Sierras Marginales thrust sheet occurred during this time period as well [Meigs et al., 1996], but the potential cooling paths modeled for our hanging wall sample fail to distinguish a narrow period of recent exhumation. It is notable that deformation and exhumation occurs across the outboard structures, despite previous findings suggesting that during this period, there is a shift from rapid denudation of the central Axial Zone [Metcalf et al., 2009] to the onset of topographic development in the western Pyrenees [Whitchurch et al., 2011].

[26] Between 25 and $20 \mathrm{Ma}$, exhumation concentrates at the boundary between the thick-skinned Axial Zone and the thin-skinned southern FTB (Figure 9c). In the eastern Nogueres Zone, rapid bedrock cooling began 29-21 Ma. Upper Eocene syntectonic conglomerates onlap thrusts in the Nogueres Zone and authigenic illite in a minor overturned proximal thrust has an age of $\sim 56 \mathrm{Ma}$ [Rahl et al., 2011], so it is clear that thrusting ceased prior to exhumation. Samples from the Freser antiformal stack and from north of the Pedraforca thrust sheet record contemporaneous exhumation between 25-20 and 27-21 Ma, respectively. These structures occupy a similar structural position to those in the Nogueres Zone at the transition between the Axial Zone and the southern FTB (Figure 8). Previous studies recognized rapid exhumation during this time period in the central Pyrenees and attributed it to antiformal stacking and underplating as a response to sediment loading on the thinskinned FTB [Sinclair et al., 2005]. Our results demonstrate that rapid exhumation at this time extends at least $100 \mathrm{~km}$ farther eastward.

[27] Late-stage (25-20 Ma) synorogenic exhumation in the Pyrenees could result from either exhumation commensurate with tectonic deformation and stable climate, or exhumation coincident with deformation and enhanced by climate change. Antiformal stack formation may have occurred synchronously along strike (Figure 9), coevally or immediately following the last phase of shortening on the southern thrust sheets after $\sim 24.7 \mathrm{Ma}$ [Meigs et al., 1996]. Sediment sourced from the Axial Zone buried and stabilized the outboard FTB structures [Coney et al., 1996], possibly causing deformation to shift toward the hinterland [Jolivet et al., 2007; this study]. This would have allowed the orogenic wedge to rebuild taper through underplating and thrusting, accommodating the final phase of convergence [Beaumont et al., 2000]. Existing thermochronometer data sets and numerical models support this idea, suggesting that rock uplift from antiformal stacking drove rapid exhumation in the south central Pyrenees during the early Miocene [Sinclair et al., 2005; Gibson et al., 2007; Jolivet et al., 2007]. However, the diachronous development of the Axial Zone as well as variations in the alongstrike structure and width of the southern FTB call into question a similar sediment loading response in the eastern Pyrenean wedge. There, in contradiction to the predictions of numerical models [Fillon et al., 2012], syntectonic sediment is preserved at higher elevations than in the central Pyrenees [Coney et al., 1996] and in greater thicknesses in the nearest foreland basin [Sinclair et al., 2005], yet the thrust sheets of the FTB are much narrower than the central Pyrenees.

[28] Alternatively, a regional or global shift to more erosive climate conditions could have initiated a pulse of rapid exhumation in the Axial Zone. Global climate in the Miocene is thought to be relatively warm and arid, peaking with the middle Miocene climatic optimum [Zachos et al., 2001]. However, recent investigations into the major element geochemistry of early Miocene paleosols from the north central Ebro Basin suggest that the regional climate was subhumid to humid, with considerably more precipitation than the earlier arid to semiarid climate during the late Oligocene [Cabrera et al., 2002; Hamer et al., 2007]. Uplift of the western Pyrenees by 30 Ma suggests that significant topography existed across the entire range [Whitchurch et al., 2011]. At present, regional climate modeling shows that orography is the principal control on precipitation patterns in Spain that favor high-altitude precipitation and sheltered lowlands [Sotillo et al., 2003]. The eastern Pyrenees in particular are subjected to high-frequency, convective rainstorms during the summer unlike elsewhere in the Mediterranean basin because of the coupling of orographic cooling and wet air masses produced by the Mediterranean Sea [Callado and Pascual, 2005]. The presence of an evaporative lacustrine environment in the Ebro Basin through the Miocene [Garcia-Castellanos et al., 2003] may have also enhanced orographic precipitation and, thus, erosion along the southern range front. A shift to a stormier, more erosive climate folloing full along-strike topographic development of the Pyrenees [Whitchurch et al., 2011] poses another explanation for our observation of uniform along-strike exhumation $\sim 25-20 \mathrm{Ma}$ at the transition between the Axial Zone and the thinskinned southern FTB. We suggest that climate-enhanced feedback between erosion and antiformal stack development during this time period is a more plausible explanation for synchronous exhumation than a taper adjustment response to sediment loading because of the structurally heterogeneous form of the FTB.

\subsection{Postorogenic Exhumation}

[29] Two samples from the central FTB record the youngest, postorogenic exhumation in the Pyrenees (Figure 9d). Syntectonic conglomerates on the eastern margin of the central thrust sheets indicate Montsec thrust motion and folding of the Oliana anticline $\sim 40-25 \mathrm{Ma}$ [Burbank et al., 1992a; Vergés and Muñoz, 1990]. Middle Eocene syntectonic conglomerates onlapping the Montsec thrust itself west of sample WT2 also bracket deformation older than 45 Ma [Meigs and Burbank, 1997]. However, model results show that the Oliana anticline and Montsec thrust sheet hanging wall both experienced rapid cooling that began during the Miocene $(<23 \mathrm{Ma})$ (Figures 6 and 7). This suggests a period of erosion that occurs after significant episodes of active shortening. Several postorogenic factors could be responsible for this exhumation. Basin modeling [Garcia-Castellanos et al., 2003], seismic imaging of the Ebro delta [Urgeles et al., 2010], and paleotopographic signals within thermochronometer data [Fillon and van der Beek, 2012] imply that capture of the 
paleo-Ebro River by the Mediterranean Sea (at $13-8.5 \mathrm{Ma}$ ) caused regional base level lowering and triggered excavation of the sediment blanket that buried both structures. Bedrock on the eastern Montsec thrust sheet began rapidly exhuming between 21 and $10 \mathrm{Ma}$ and may corroborate these conclusions with direct evidence from the excavated region. However, the Oliana anticline exhumation began 18-16 Ma, well before regional base level lowering. Thermokinematic modeling of thermochronometer data from the Axial Zone ruled out climate change as an important factor in the postorogenic evolution of the Pyrenees [Fillon and van der Beek, 2012], yet our findings suggest that increased storminess may have enhanced erosion along the southern range front and could have been an impetus for exhumation. Finally, late Oligocene to early Miocene tilting near the southeast margin of the Ebro Basin, caused by lithospheric extension and thinning, coeval with opening of the Valencia Trough, may also enhance exhumation along large areas paralleling the range [Lewis et al., 2000]. More detailed sampling and combined AFT and (U-Th)/He dating in apatite (closure temperature $\sim 70^{\circ} \mathrm{C}$ [Farley, 2000]) could test if this early Miocene exhumation event is robust.

\section{Conclusions}

[30] This study documents Cenozoic exhumation across the fold-thrust belt of the southern Pyrenees with 18 new bedrock apatite fission track (AFT) samples. Comparison between the AFT cooling histories and sample deposition timing differentiates between sedimentary bedrock retaining an inherited unroofing signal from the range interior (Axial Zone) and recording exhumation after incorporation into the Pyrenean thrust sheets. Graus-Tremp syntectonic piggyback basin sediments record Axial Zone exhumation 70-40 Ma, consistent with detrital exhumation signals present in AFT samples from other nearby piggyback basins [Beamud et al., 2010; Rahl et al., 2011]. AFT samples from other southern Pyrenean structures are partially or fully reset, recording FTB exhumation in excess of $\sim 3 \mathrm{~km}$. The Cadi thrust sheet exhumed between 34 and $29 \mathrm{Ma}$, contemporaneous with its final phase of deformation 36-30 Ma. Reset cooling ages from the Oliana anticline and southern edge of the Montsec thrust sheet reflect post-tectonic exhumation 20-10 Ma, perhaps in response to fluvial incision from abrupt foreland base level change and/ or regional tilting coeval with Valencia Trough extension. Basement rocks at the transition from the cover thrust sheets to the crustal-scale duplex of the Axial Zone record exhumation along the central to eastern FTB at 25-20 Ma. This rapid exhumation may result from antiformal stack development in response to either (a) sediment loading, previously noted in the Nogueres Zone of the central Pyrenees [Sinclair et al., 2005], and/or (b) a shift to more erosive climate conditions in the early Miocene. We favor the latter explanation because of the high degree of structural heterogeneity between the central and the eastern FTB.

\section{Appendix A: Analytical Procedures}

[31] All AFT analyses were performed at Apatite to Zircon, Inc. Samples were crushed and sieved to sand-sized particles, then apatite grains were isolated using standard gravimetric and magnetic mineral separation techniques [Donelick et al., 2005]. Grains were mounted in epoxy resin, cured at $90^{\circ} \mathrm{C}$ for $1 \mathrm{~h}$, and then polished to expose the internal surfaces of the grains. Mounts were then immersed in $5.5 \mathrm{M}$ $\mathrm{HNO}_{3}$ for $20 \mathrm{~s}$ at $21^{\circ} \mathrm{C}$ to reveal natural fission tracks that intersected the polished grain surface. Samples were irradiated with ${ }^{252} \mathrm{Cf}$ to facilitate fission track length measurement [Donelick and Miller, 1991]. Fission track lengths and crystallographic orientation were measured using a digitizing tablet interfaced with a computer at $2000 \mathrm{x}$ magnification under unpolarized light. Only natural, horizontal, confined fission tracks with clearly visible ends were measured. The mean $D_{\text {par }}$ was determined for each grain by measuring up to four etch pit diameters. Fission track grain ages were calculated using a modified form of the radioactive decay equation and the ratio of the number of fission tracks present to the concentration of ${ }^{238} \mathrm{U}$ measured using laser ablation inductively coupled plasma-mass spectrometry (LA-ICP-MS) [Donelick et al., 2005; Hasebe et al., 2004]. This decay equation includes a zeta calibration factor, which was determined by analyzing Durango and Fish Canyon apatite $(30.6 \pm 0.3 \mathrm{Ma}$ from Cerro de Mercado, Durango, Mexico, and $27.9 \pm 0.7 \mathrm{Ma}$ from the San Juan Mountains, CO, U.S.) at the beginning and end of each LA-ICP-MS session for its U/Ca ratio.

\section{Appendix B: Thermal Modeling}

[32] We performed inverse thermal modeling of our AFT data using the software HeFTy version 1.7.4 [Ketcham, 2005]. We used the multikinetic annealing model of Ketcham et al. [1999] and included $D_{\text {par }}$ values. We projected the track lengths to the crystallographic $c$ axis [Donelick et al., 1999] and included ${ }^{252} \mathrm{Cf}$ irradiation.

[33] Open-ended modeling was performed with all sample data as one kinetic population with a starting temperature of (1) $200^{\circ} \mathrm{C}$ at a time that is $50 \mathrm{Ma}$ older than deposition and (2) $20^{\circ} \mathrm{C}$ at present (after Barnes et al. [2006, 2008]). We ran this model to assess how distinct the recent cooling history is without bias from user-defined constraints. We then simulated source region exhumation and subsequent incorporation of apatite grains into sedimentary bedrock samples by forcing the time-temperature paths to travel from depth $\left(200^{\circ} \mathrm{C}\right) 50 \mathrm{My}$ before sample deposition to surficial conditions $\left(10^{\circ} \mathrm{C}-30^{\circ} \mathrm{C}\right)$ during deposition, then to reheat $\left(50^{\circ} \mathrm{C}-180^{\circ} \mathrm{C}\right)$ between deposition and $1 \mathrm{Ma}$ before returning to the surface $\left(20^{\circ} \mathrm{C}\right)$ by the present. By comparing the two models, we could confirm that the refined model better constrains the same cooling event as the open-ended model, ensuring that we imposed realistic modeling parameters that did not remove the intrinsic cooling history. We designated each time-temperature cooling path segment to be monotonic for simplicity. For maximum flexibility [see Ketcham, 2005], thermal history segments between each imposed $t-T$ constraints were designated as episodic style, random spacing, with the largest number of vertices (halved 5 times). We enforced a maximum slope of $40^{\circ} \mathrm{C} / \mathrm{My}$, assuming that cooling rates on the FTB structures will be similar to or lower than those in the Axial Zone [e.g., Metcalf et al., 2009]. We ran each inversion with a Monte Carlo search and 50,000 attempted paths. 
ET1

Central value $=25.3+/-6$ (2se)

Dispersion $=60 \%$

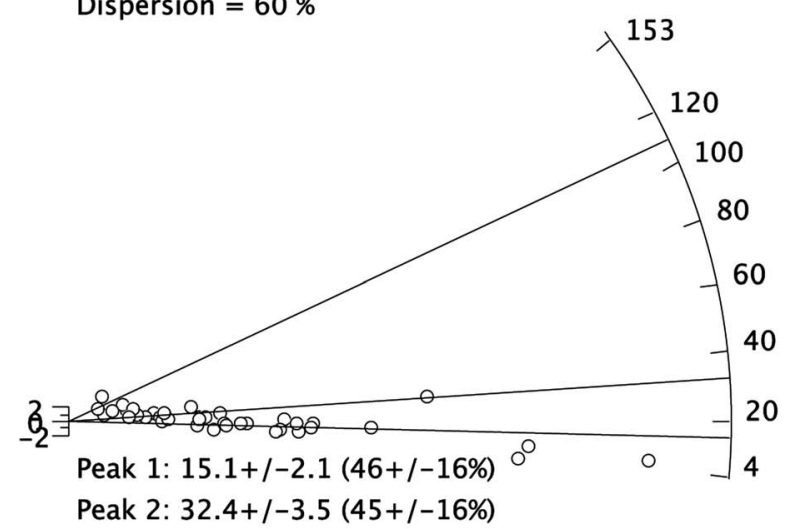

Peak 3: $109+/-22(9+/-23 \%)$

se $\begin{array}{lllll}10025 \quad 10 & 5 & 2\end{array}$

Central value $=34.8+/-6.45$ (2se)

Dispersion $=27.5 \%$

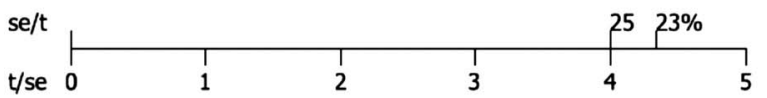

CWT1

Central value $=45.9+/-10.3$ (2se)

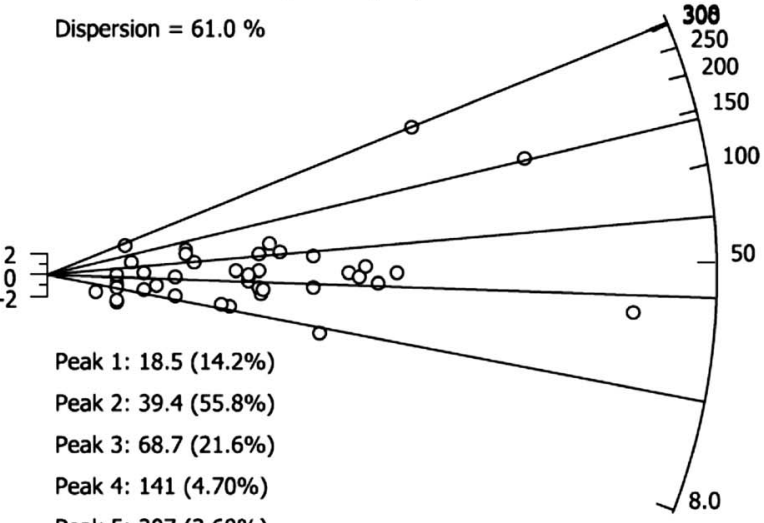

Peak 5: 307 (3.68\%)

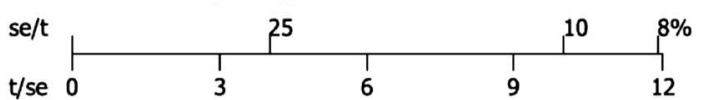

ET2

Central value $=26.2+/-6.59$ (2se)

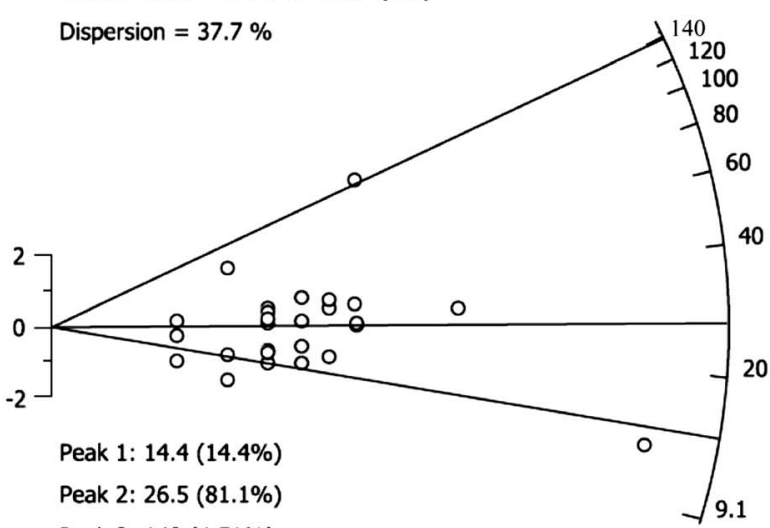

Peak 3: $140(4.51 \%)$

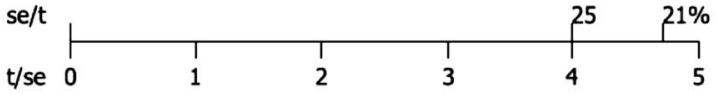

CET2

Central value $=24.1+/-2.62(2 \mathrm{se})$

Dispersion $=20.6 \%$
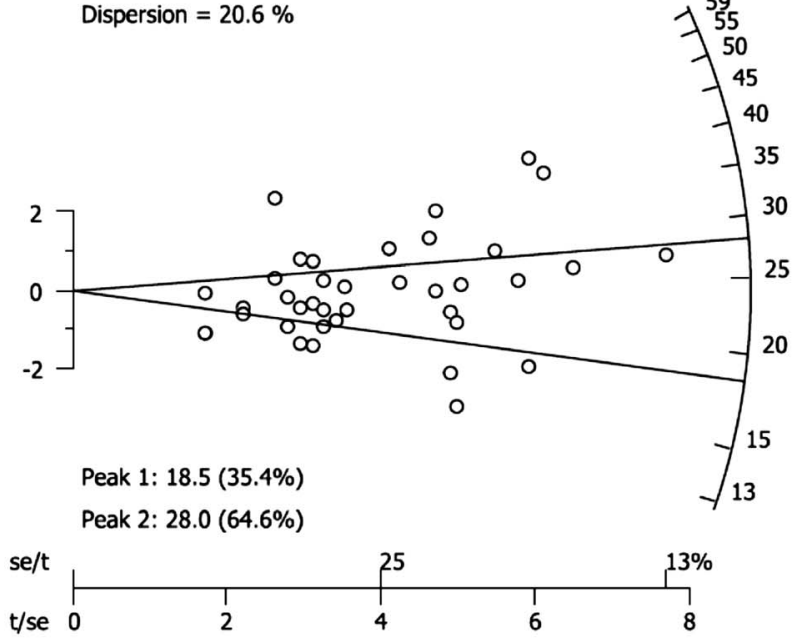

CWT3

Central value $=28.4+/-2.22$ (2se)

Dispersion $=16.3 \%$

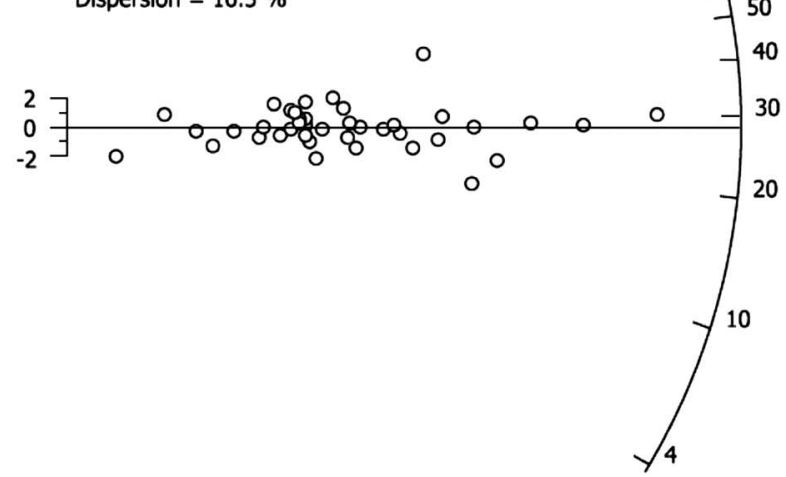

Peak 1: 28.3 (100\%)

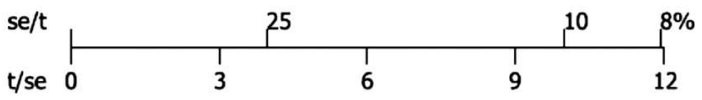


CWT4

Central value $=33.8+/-6.73(2 \mathrm{se})$

Dispersion $=33.5 \%$

Peak 1: $33.7(100.0 \%)$

se/

t/se 0

WT3

Central value $=79.5+/-14.3(2 \mathrm{se})$

Dispersion $=52.9 \%$

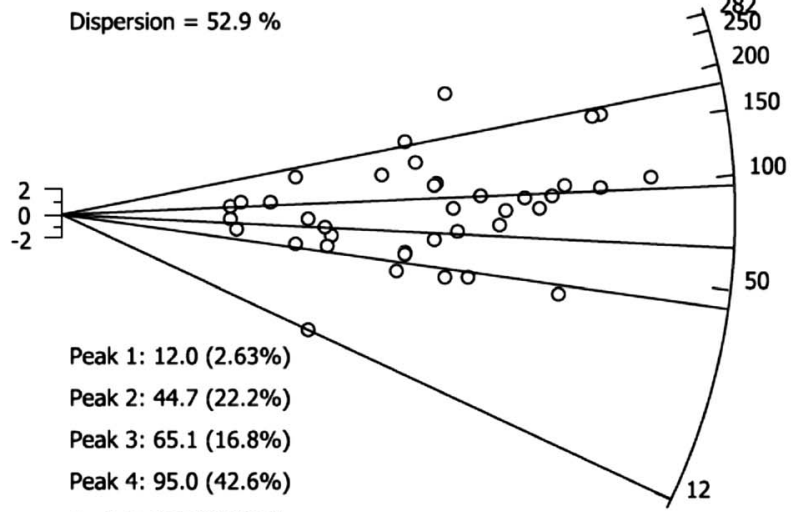

Peak 5: $177(15.8 \%)$

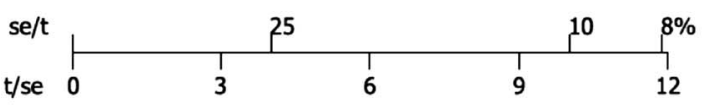

WT5

Central value $=96.6+/-73.5$ (2se)

Dispersion $=120 \%$

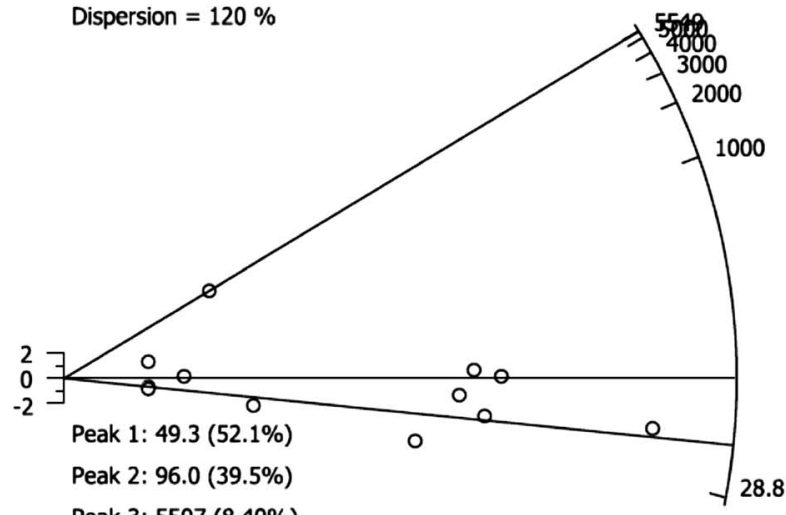

Peak 3: 5507 (8.40\%)

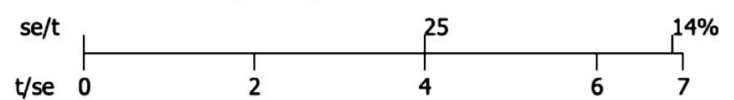

WT2

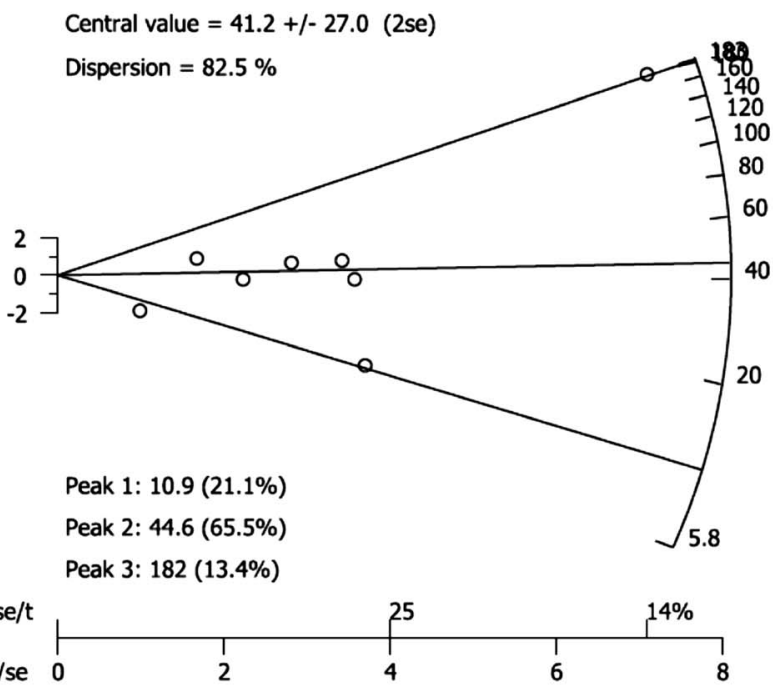

WT4

Central value $=50.0+/-12.5(2 \mathrm{se})$

Dispersion $=36.7 \%$

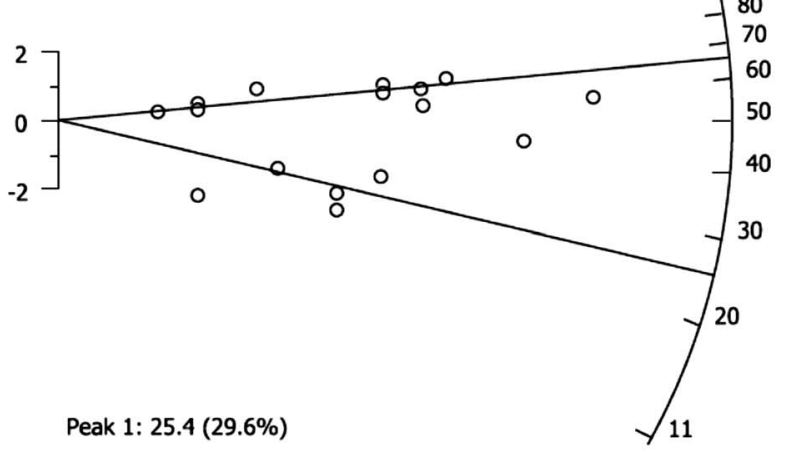

Peak 2: $65.6(70.4 \%)$

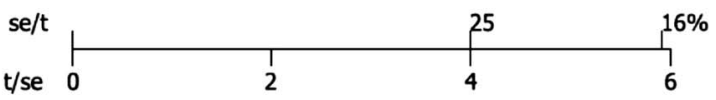

WT6

Central value $=49.2+/-6.79$ (2se)

Dispersion $=37.2 \%$
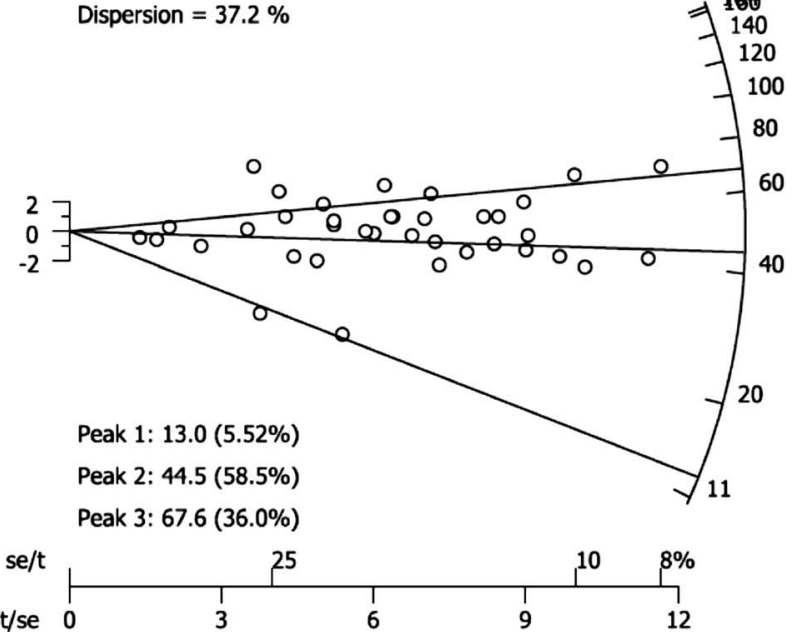

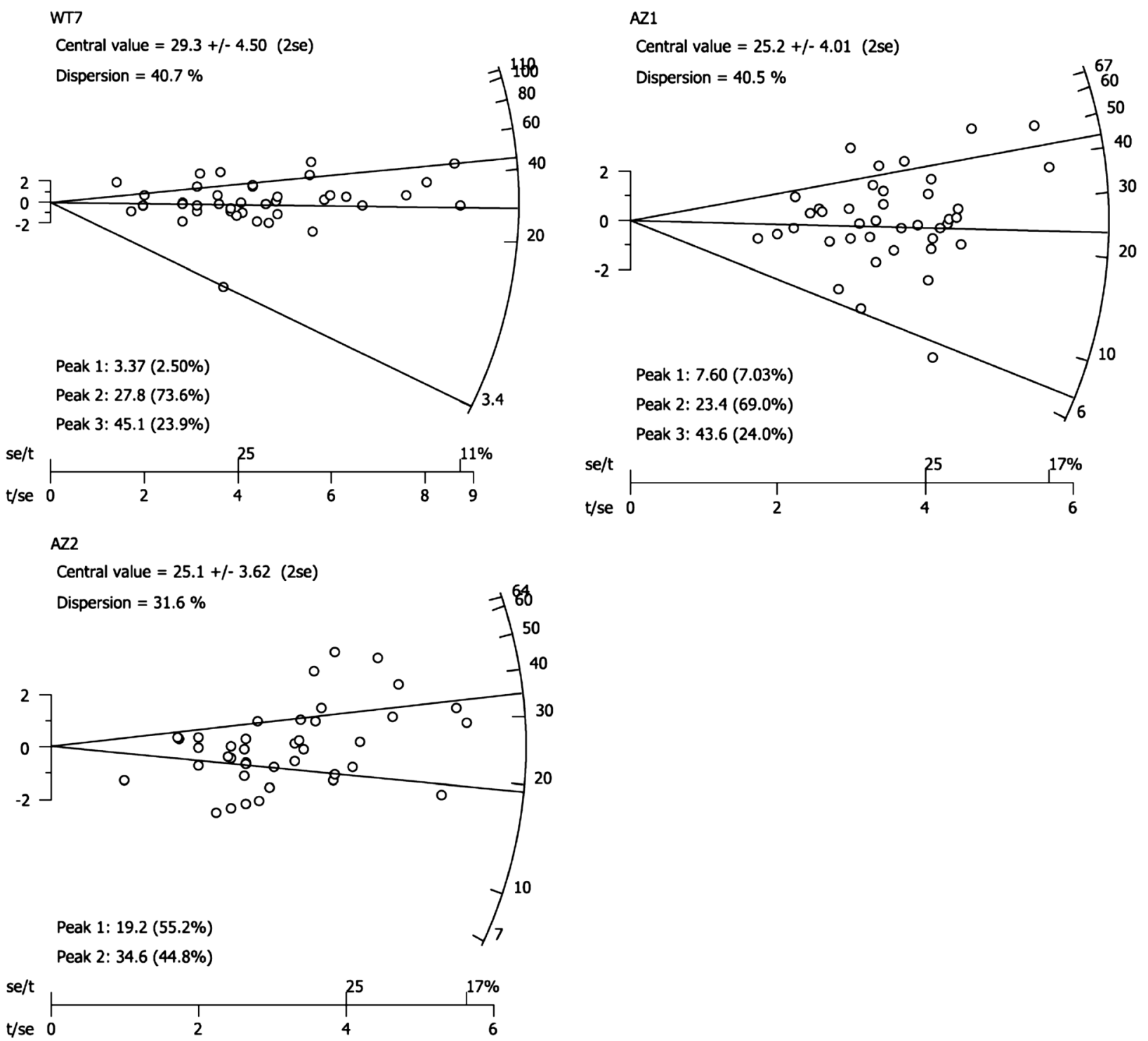

Figure C1. Central and component ages determined for our samples using RadialPlotter [Vermeesch, 2009]. The radial plot displays the single grain age as the degree of rotation along the curved axis, and the analytical uncertainty as the distance from the curved axis. Component ages are shown as the radiating lines.

\section{Appendix C: RadialPlotter Results}

[34] We determined AFT central and component ages with the Java application RadialPlotter version 4.4 [Vermeesch, 2009]. We generated radial plots for our LA-ICP-MS data from single grain ages using the Other input, not the Fission Tracks input that is designed for the external detector method. We linearly transformed our data and used an automated mixing model to generate the radial plots shown in Figure $\mathrm{Cl}$.

[35] Acknowledgments. Financial support was provided by NSF EAR 0724656 to T. Ehlers and a University of Michigan Scott Turner Award in the Earth Sciences to J. Barnes for the fieldwork. We thank Matthias Bernet and an anonymous reviewer for thoughtful, thorough comments that greatly improved this manuscript.

\section{References}

Allen, P. A. (2008), From landscapes into geological history, Nature, 451, $274-276$.
Arche, A., G. Evans, and E. Clavell (2010), Some considerations on the initiation of the present SE Ebro river drainage system: Post- or pre-Messinian?, J. Iber. Geol., 36(1) 73-85.

Barnes, J. B., T. A. Ehlers, N. McQuarrie, P. B. O'Sullivan, and J. D. Pelletier (2006), Eocene to recent variations in erosion across the central Andean fold-thrust belt, northern Bolivia: Implications for plateau evolution, Earth Planet. Sci. Lett., 248, 118-133.

Barnes, J. B., T. A. Ehlers, N. McQuarrie, P. B. O'Sullivan, and S. Tawackoli (2008), Thermochronometer record of central Andean Plateau growth, Bolivia (19.5 S), Tectonics, 27, TC3003, doi:10.1029/2007TC002174.

Batt, G. E., and M. T. Brandon (2002), Lateral thinking: 2-D interpretation of thermochronology in convergent orogenic settings, Tectonophysics, 349, 185-201.

Beamud, E., J. A. Muñoz, P. G. Fitzgerald, S. L. Baldwin, M. Garcés, L. Cabrera, and J. R. Metcalf (2010), Magnetostratigraphy and detrital apatite fission track thermochronology in syntectonic conglomerates: Constraints on the exhumation of the South-Central Pyrenees, Basin Res., 23, 309-331.

Beaumont, C., P. Fullsack, and J. Hamilton (Eds.) (1992), Erosional control of active compressional orogens, in Thrust Tectonics, pp. 1-18, Chapman and Hall, London.

Beaumont, C., J. A. Muñoz, J. Hamilton, and P. Fullsack (2000), Factors controlling the Alpine evolution of the central Pyrenees inferred from a comparison of observations and geodynamical models, J. Geophys. Res., 105, 8121-8145. 


\section{RUSHLOW ET AL.: EXHUMATION OF THE SOUTHERN PYRENEES}

Brandon, M. T., M. K. Roden-Tice, and J. I. Garver (1998), Late Cenozoic exhumation of the Cascadia accretionary wedge in the Olympic Mountains, northwest Washington State, Geol. Soc. Am. Bull., 110(8), 985-1009.

Burbank, D. W., J. Vergés, J. A. Muñoz, and P. Bentham (1992a), Coeval hindward- and forward-imbricating thrusting in the south-central Pyrenees, Spain: Timing and rates of shortening and deposition, Geol. Soc. Am. Bull., 104, 3-17.

Burbank, D. W., C. Puigdefäbregas, and J. A. Muñoz (1992b), The chronology of the Eocene tectonic and stratigraphic development of the eastern Pyrenean foreland basin, northeast Spain, Geol. Soc. Am. Bull., 104, 1101-1120.

Cabrera, L., M. Cabrera, R. Gorchs, and F. X. C. de las Heras (2002), Lacustrine basin dynamics and organosulphur compound origin in a carbonate-rich lacustrine system (Late Oligocene Mequinenza Formation, SE Ebro Basin, NE Spain), Sediment. Geol., 148, 289-317.

Callado A. and R. Pascual (2005), Diagnosis and modelling of a summer convective storm over the Mediterranean Pyrenees, Adv. Geosci., 2, 273-277.

Capote, R., J. A. Muñoz, J. L. Simon, C. L. Liesa, and 1. E. Arlegui (2002), Alpine Tectonics I: The Alpine System north of the Betic Cordillera, in The Geology of Spain, edited by W. Gibbons and T. Moreno, pp. 367-400, Geol. Soc., Bath, U. K.

Carlson, W. D., R. A. Donelick, and R. A. Ketcham (1999), Variability of apatite fission-track annealing kinetics: I. Experimental results, Am. Mineral., 84, 1213-1223.

Catalunya, I. C. d. (2003), Mapa geologic de Catalunya 1:250,000, Barcelona.

Chapple, W. M. (1978), Mechanics of thin-skinned fold-and-thrust belts, Geol. Soc. Am. Bull., 89, 1189-1198.

Coney, P. J., J. A. Muñoz, K. R. McClay, and C. A. Evenchick (1996), Syntectonic burial and post-tectonic exhumation of the southern Pyrenees foreland fold-thrust belt, J. Geol. Soc. London, 153, 9-16.

Costa, E., M. Garcés, M. López-Blanco, E. Beamud, M. Gomez-Paccard and J. C. Larrasoaña (2009), Closing and continentalization of the South Pyrenean foreland basin (NE Spain): Magnetochronological constraints, Basin Res., 22, 904-917, doi:10.1111/j.1365-2117.2009.00452.x.

Dahlen, F. A., J. Suppe, and D. Davis (1984), Mechanics of fold-and-thrust belts and accretionary wedges: cohesive Coulomb theory, J. Geophys. Res., 89(B12), 10,087-10,101.

Davis, D., J. Suppe, and F. A. Dahlen (1983), Mechanics of fold-and-thrust belts and accretionary wedges, J. Geophys. Res., 88(B2), 1153-1172.

Dodson, M. H. (1973), Closure temperature in cooling geochronological and petrological systems, Contrib. Mineral. Petrol., 40, 259-274.

Donelick, R. A., and D. S. Miller (1991), Enhanced tint fission track densities in low spontaneous track density apatites using 252Cf-derived fission fragment tracks: A model and experimenta observations, Nucl. Tracks Radiat. Meas., 18(3), 301-307, doi:10.1016/ 1359-0189(91)90022-a.

Donelick, R. A., R. A. Ketcham, and W. D. Carson (1999), Variability of apatite fission-track annealing kinetics: II. Crystallographic orientation effects, Am. Mineral., 84, 1224-1234.

Donelick, R. A., P. B. O'Sullivan, and R. A. Ketcham (2005), Apatite fission-track analysis, Rev. Mineral. Geochem., 58, 49-94.

Ehlers, T. A. (2005), Crustal thermal processes and the interpretation of thermochronometer data, Rev. Mineral. Geochem., 58, 315-350.

Farley, K. A. (2000), Helium diffusion from apatite: General behavior as illustrated by Durango fluorapatite, J. Geophy. Res., 105(B2), 29032914, doi:10.1029/1999JB900348.

Filleaudeau, P.-Y., F. Mouthereau, and R. Pik (2011), Thermo-tectonic evolution of the south-central Pyrenees from rifting to orogeny: Insights from detrital zircon $\mathrm{U} / \mathrm{Pb}$ and $(\mathrm{U}-\mathrm{Th}) / \mathrm{He}$ thermochronometry, Basin Res., 23, 401-417, doi:10.1111/j.1365-2117.2011.00535.x.

Fillon, C., and P. van der Beek (2012), Post-orogenic evolution of the southern Pyrenees: Constraints from inverse thermo-kinematic modelling of low-temperature thermochronology data, Basin Res., 24, 418-436, doi:10.1111/j.1365-2117.2011.00533.x.

Fillon, C., P. van der Beek, and C. Gautheron (2010), Post-orogenic evolution of the Southern Pyrenees: Thermokinematic modeling and (U-Th)/He dating, in Thermo2010 12th International Conference on Thermochronology, p. 306, Univ. of Glasgow, Glasgow.

Fillon, C., Huismans, R., and P. van der Beek (2012), Syntectonic sedimentation effects on the growth of fold-and-thrust belts, Geology, 41, 83-86, doi:10.1130/G33531.1.

Fitzgerald, P. G., J. A. Muñoz, P. J. Coney, and S. L. Baldwin (1999), Asymmetric exhumation across the Pyrenean orogen: Implications for the tectonic evolution of a collisional orogen, Earth Planet. Sci. Lett., 173, 157-170.

Fleischer, R. L., P. B. Price, and R. M. Walker (1975), Nuclear Tracks in Solids, Univ. of Calif. Press, Berkeley.

Galbraith, R. F. (1981), On statistical models for fission track counts, J. Int Assoc. Math. Geol., 13, 471-478.

Galbraith, R. F., and P. F. Green (1990), Estimating the component ages in a finite mixture, Nucl. Tracks Radiat. Meas., 17, 197-206.
Gallagher, K., R. Brown, and C. Johnson (1998), Fission track analysis and its applications to geological problems, Annu. Rev. Earth Planet. Sci., 26, 519-572.

Garcia-Castellanos, D., J. Vergés, J. Gaspar-Escribano, and S. Cloetingth (2003), Interplay between tectonics, climate, and fluvial transport during the Cenozoic evolution of the Ebro Basin (NE Iberia), J. Geophys. Res., 108(B7), 2347, doi:10.1029/2002JB002073.

Gilchrist A. R., M. A. Summerfield and H. A. P. Cockburn (1994), Landscape dissection, isostatic uplift, and the morphologic development of orogens, Geology, 22, 963-966.

Gibson, M., H. D. Sinclair, G. J. Lynn, and F. M. Stuart (2007), Late- to postorogenic exhumation of the Central Pyrenees reveal through combined thermochronological data and modelling, Basin Res., 19, 323-334.

Gleadow, A. J. W., I. R. Duddy, P. F. Green, and J. F. Lovering (1986), Confined fission track lengths in apatite: A diagnostic tool for thermal history analysis, Contrib. Mineral. Petrol., 94, 405-415.

Gradstein, F. M., et al. (2005), A Geologic Time Scale 2004, 610 pp. Cambridge Univ. Press, Cambridge, U. K.

Green, P. F. (1981), A new look at statistics in fission-track dating, Nucl. Tracks Radiat. Meas., 5, 77-86.

Gunnell Y., M. Calvet, S. Brichau, A. Carter, J.-P. Aguilar and H. Zeyen (2009), Low long-term erosion rates in high-energy mountain belts Insights from thermo- and biochronology in the Eastern Pyrenees, Earth Planet. Sci. Lett., 278, 208-218.

Haines, S. H. (2008), Transformations in clay-rich fault rocks: Constraining fault zone processes and the kinematic evolution of regions, $42 \mathrm{pp}$., Univ. of Mich., Ann Arbor.

Hamer, J. M. M., N. D. Sheldon, and G. J. Nichols (2007), Global aridity during the early Miocene? A terrestrial paleoclimate record from the Ebro Basin, Spain, J. Geol., 114, 601-608.

Hasebe, N., J. Barbarand, K. Jarvis, A. Carter, and A. J. Hurford (2004), Apatite fission-track chronometry using laser ablation ICP-MS, Chem Geol., 207(3-4), 135-145, doi:10.1016/j.chemgeo.2004.01.007.

Hogan, P. J., and D. W. Burbank (1996), Evolution of the Jaca piggyback basin and emergence of the External Sierra, southern Pyrenees, in Tertiary Basins of Spain, edited by P. F. Friend and C. J. Dabrio, pp. 153-160, Cambridge Univ. Press, Cambridge, U.K.

Jolivet, M., P. Labaume, P. Moñie, M. Brunel, N. Arnaud, and M. Campani (2007), Thermochronology constraints for the propogation sequence of the south Pyrenean basement thrust system (France-Spain), Tectonics, 26, TC5007, doi:10.1029/2006TC002080.

Ketcham, R. A. (2005), Forward and inverse modeling of low-temperature thermochronometry data, Rev. Mineral. Geochem., 58, 275-314.

Ketcham, R. A., R. A. Donelick, and W. D. Carlson (1999), Variability of apatite fission-track annealing kinetics: III. Extrapolation to geological time scales, Am. Mineral., 84, 1235-1255.

Lewis, C. J., J. Vergés, and M. Marzo (2000), High mountains in a zone of extended crust: Insights into the Neogene-Quaternary topographic development of northeastern Iberia, Tectonics, 19, 86-102.

Meigs, A. J., and D. W. Burbank (1997), Growth of the south Pyrenean orogenic wedge, Tectonics, 16(2), 239-258.

Meigs, A. J., J. Vergés, and D. W. Burbank (1996), Ten-million-year history of a thrust sheet, Geol. Soc. Am. Bull., 108(12), 1608-1625.

Metcalf, J. R., P. G. Fitzgerald, S. L. Baldwin, and J.-A. Muñoz (2009), Thermochronology of a convergent orogen: Constraints on the timing of thrust faulting and subsequent exhumation of the Maladeta Pluton in the Central Pyrenean Axial Zone, Earth Planet. Sci. Lett., 287, 488-503.

Morris, R. G., H. D. Sinclair, and A. J. Yelland (1998), Exhumation of the Pyrenean orogen: Implications for sediment discharge, Basin Res., 10, 69-85.

Mugnier, J. L., P. Baby, B. Colletta, P. Vinour, P. Bale, and P. Leturmy (1997), Thrust geometry controlled by erosion and sedimentation: A view from analogue models, Geology, 25(5), 427-430.

Muñoz, J. A. (1992), Evolution of a continental collision belt: ECORSPyrenees crustal balanced cross-section, in Thrust Tectonics, edited by K. R. McClay, pp. 235-246, Chapman and Hall, London.

Muñoz, J. A., A. Martínez, and J. Vergés (1986), Thrust sequences in the eastern Spanish Pyrenees, J. Struct. Geol., 8, 399-405.

Rahl, J. M., S. H. Haines, and B. A. van der Pluijm (2011), Links between orogenic wedge deformation and erosional exhumation: Evidence from illite age analysis of fault rock and detrital thermochronology of syntectonic conglomerates in the Spanish Pyrenees, Earth Planet. Sci. Lett., 307, 180-190.

Ramos, E., P. Busquets, and J. Vergés (2002), Interplay between longitudinal fluvial and transverse alluvial fan systems and growing thrusts in a piggyback basin (SE Pyrenees), Sediment. Geol., 146, 105-131.

Reiners, P. W., and M. T. Brandon (2006), Using thermochronology to understand orogenic erosion, Annu. Rev. Earth Planet. Sci., 34, 419-466.

Roure, F., P. Choukroune, X. Berastegui, J. A. Muñoz, A. Villien, P. Matheron, M. Bareyt, M. Séguret, P. Camara, and J. Déramond (1989), ECORS deep 


\section{RUSHLOW ET AL.: EXHUMATION OF THE SOUTHERN PYRENEES}

seismic data and balanced cross sections: Geometric constraints on the evolution of the Pyrenees, Tectonics, 8, 41-50.

Sibuet, J.-C., S. P. Srivastava, and W. Spakman (2004), Pyrenean orogeny and plate kinematics, J. Geophys. Res., 109, B08104, doi:10.1029/ 2003JB002514.

Sinclair, H. D., M. Gibson, M. Naylor, and R. G. Morris (2005), Asymmetric growth of the Pyrenees revealed through measurement and modeling of orogenic fluxes, Am. J. Sci., 305, 369-406.

Sotillo, M. G., C. Ramis, R. Romero, S. Alonso, and V. Homar (2003), Role of orography in the spatial distribution of precipitation over the Spanish Mediterranean zone, Clim. Res., 23, 247-261.

Tagami, T., and P. B. O'Sullivan (2005), Fundamentals of fission-track thermochronology, Rev. Mineral. Geochem., 58, 19-47.

Teixell, A. (1998), Crustal structure and orogenic material budget in the west central Pyrenees, Tectonics, 17(3), 395-406.

Urgeles, R., A. Camerlenghi, D. Garcia-Castellanos, B. De Mol, M. GArces, J. Vergés, I. HAslam, and M. Hardin (2010), New constraints on the Messinian sealevel drawdown from 3D seismic data of the Ebro Margin, Basin Res., 23, 123-145, doi:10.1111/j.1365-2117.2010.00477.x.

Vergés, J. (1999), Estudi geologic del vessant sud del Pirineu oriental i central. Evolucio cinematica en 3D., Monogr. Tec., 7, 192 pp., Serv. Geol.

Vergés, J., and J. A. Muñoz (1990), Thrust sequences in the southern central Pyrenees, Bull. Soc. Geol. Fr., 8, 265-271.

Vergés, J., H. Millán, E. Roca, J. A. Muñoz, M. Marzo, J. Cires, T. D. Bezemer, R. Zoetemeijer, and S. Cloetingth (1995), Eastern Pyrenees and related foreland basins: pre-, syn-, and post-collisional crustal-scale cross-sections, Mar. Petrol. Geol., 12(8), 893-915.

Vergés, J., and D. W. Burbank (Eds.) (1996), Eocene-Oligocene thrusting and basin configuration in the eastern and central Pyrenees (Spain), in World and Regional Geology, vol 6, chap. E-11, 120-133, Cambridge Univ. Press, Cambridge, U. K.

Vergés, J., M. Fernàndez, and A. Martínez (2002), The Pyrenean orogen: pre-, syn-, and post-collisional evolution, J. Virtual Explor., 8, 55-74.

Vermeesch, P. (2008), RadialPlotter: A Java application for fission track, luminescence and other radial plots, Radiat. Meas., 44(4), 409-410.

Whipple, K. X. (2009), The influence of climate on the tectonic evolution of mountain belts, Nat. Geosci., 2, 97-104.

Whitchurch, A. L., A. Carter, H. D. Sinclair, R. A. Duller, A. C. Whittaker, and P. A. Allen (2011), Sediment routing system evolution within a diachronously uplifting orogen: Insights from detrital zircon thermochronological analyses from the south-central Pyrenees, Am. J. Sci., $311,442-482$.

Willett, S. D. (1999), Orogeny and orography: The effects of erosion on the structure of mountain belts, J. Geophys. Res., 104(B12), 28,957-28981.

Willett, S. D., C. Beaumont, and P. Fullsack (1993), Mechanical model for the tectonics of doubly vergent compressional orogens, Geology, 21, 371-374.

Zachos, J. C., M. Pagani, L. Sloan, E. Thomas, and K. Billups (2001), Trends, rhythms, and aberrations in global climate $65 \mathrm{Ma}$ to present, Science, 292, 686-693. 